GOV"

I 19.3

$1754-D$

\title{
Mineral Resources of the \\ Negro Bill Canyon Wilderness Study Area, Grand County, Utah
}
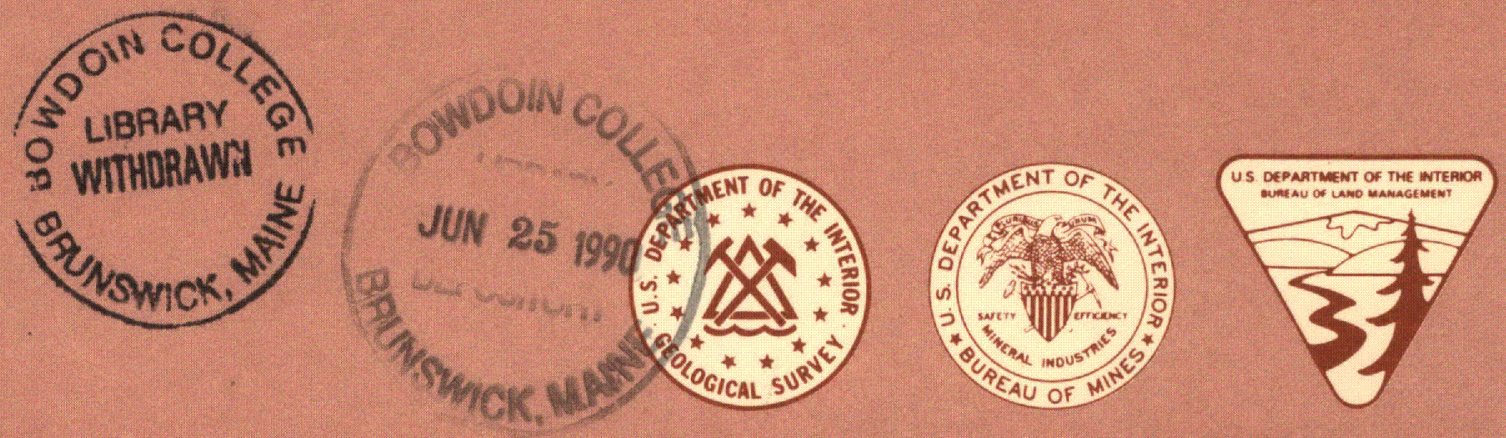

\section{U.S. GEOLOGICAL SURVEY BULLETIN 1754-D}

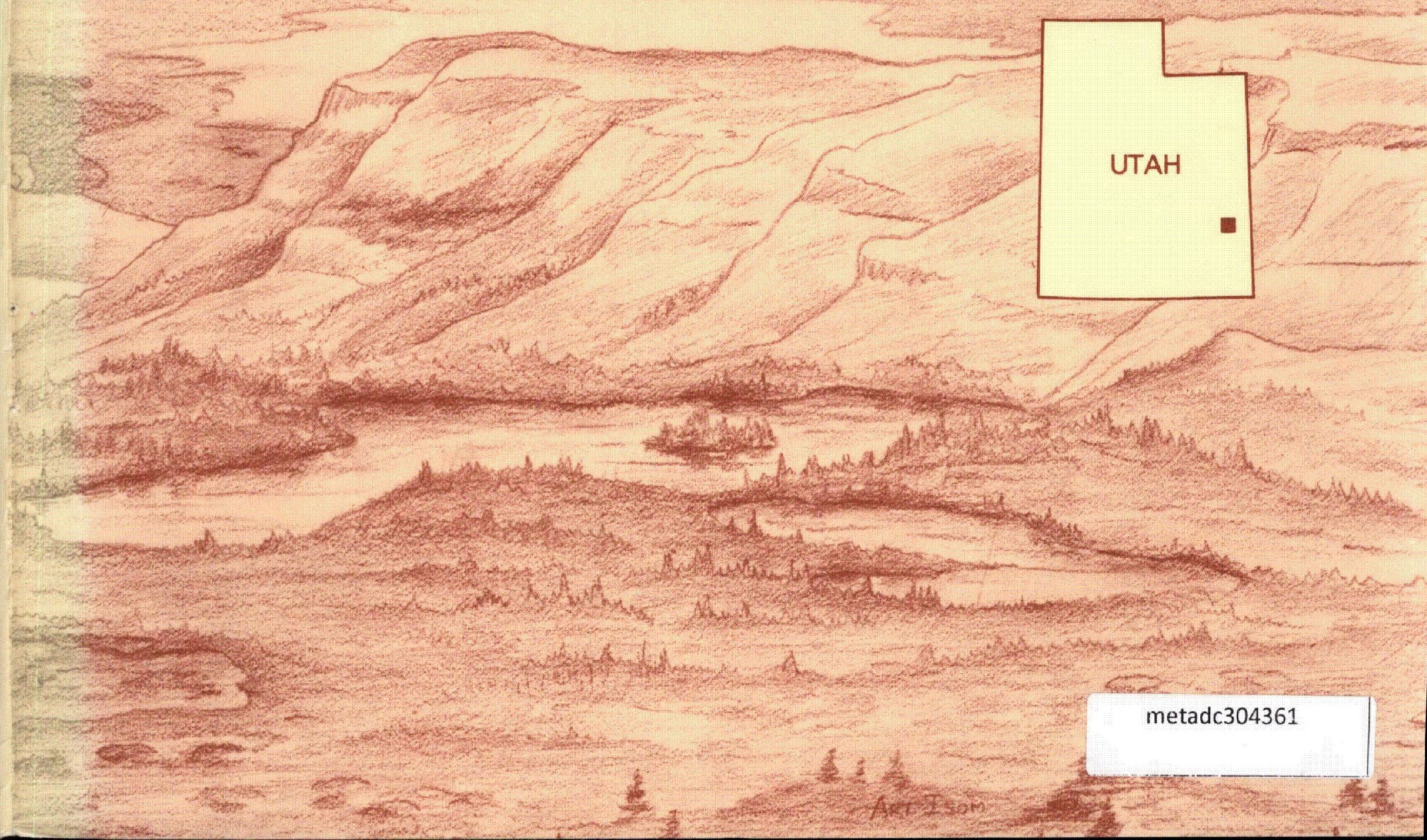




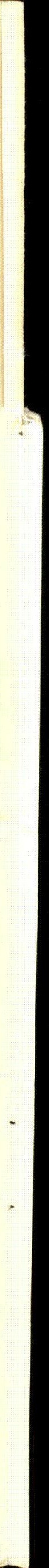


Chapter D

\section{Mineral Resources of the \\ Negro Bill Canyon Wilderness Study Area, Grand County, Utah}

By SUSAN BARTSCH-WINKLER, JAMES E. CASE, HARLAN N. BARTON, and JOSEPH S. DUVAL U.S. Geological Survey

MICHAEL E. LANE

U.S. Bureau of Mines 


\title{
DEPARTMENT OF THE INTERIOR
}

\section{MANUEL LUJAN, JR., Secretary}

\section{U.S. GEOLOGICAL SURVEY}

\author{
Dallas L. Peck, Director
}

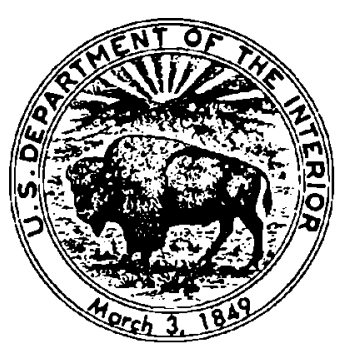

Any use of trade, product, or firm names in this publication is for descriptive purposes only and does not imply endorsement by the U.S. Government.

For sale by the

Books and Open-File Reports Section

U.S. Geological Survey

Federal Center, Box 25425

Denver, CO 80225

\section{Library of Congress Cataloging-In-Publication Data}

Mineral resources of the Negro Bill Canyon Wilderness Study Area, Grand

County, Utah / by Susan Bartsch-Winkler ... [et al.].

p. $\quad \mathrm{cm}$. - (Mineral resources of wilderness study areas-upper

Colorado River region, Utah ; ch. D) (U.S. Geological Survey bulletin :

1754-D)

Includes bibliographical references.

Supt. of Docs. no.: I 19.3: 1754-D

1. Mines and mineral resources-Utah-Negro Bill Canyon

Wilderness. 2. Negro Bill Canyon Wilderness (Utah) I. Bartsch-Winkler,

S. II. Series. III. Series: U.S. Geological Survey bulletin ; 1754-D.

QE75.B9

[TN24.U8]

$557.3 \mathrm{~s}-\mathrm{dc} 20$

89-600196

[553'.09792'58] 


\section{STUDIES RELATED TO WILDERNESS}

\section{Bureau of Land Management Wilderness Study Areas}

The Federal Land Policy and Management Act (Public Law 94-597, October 21, 1976) requires the U.S. Geological Survey and the U.S. Bureau of Mines to conduct mineral surveys on certain areas to determine the mineral values, if any, that may be present. Results must be made available to the public and be submitted to the President and the Congress. This report presents the results of a mineral survey of the Negro Bill Canyon (UT-060-138) Wilderness Study Area, Grand County, Utah. 



\section{CONTENTS}

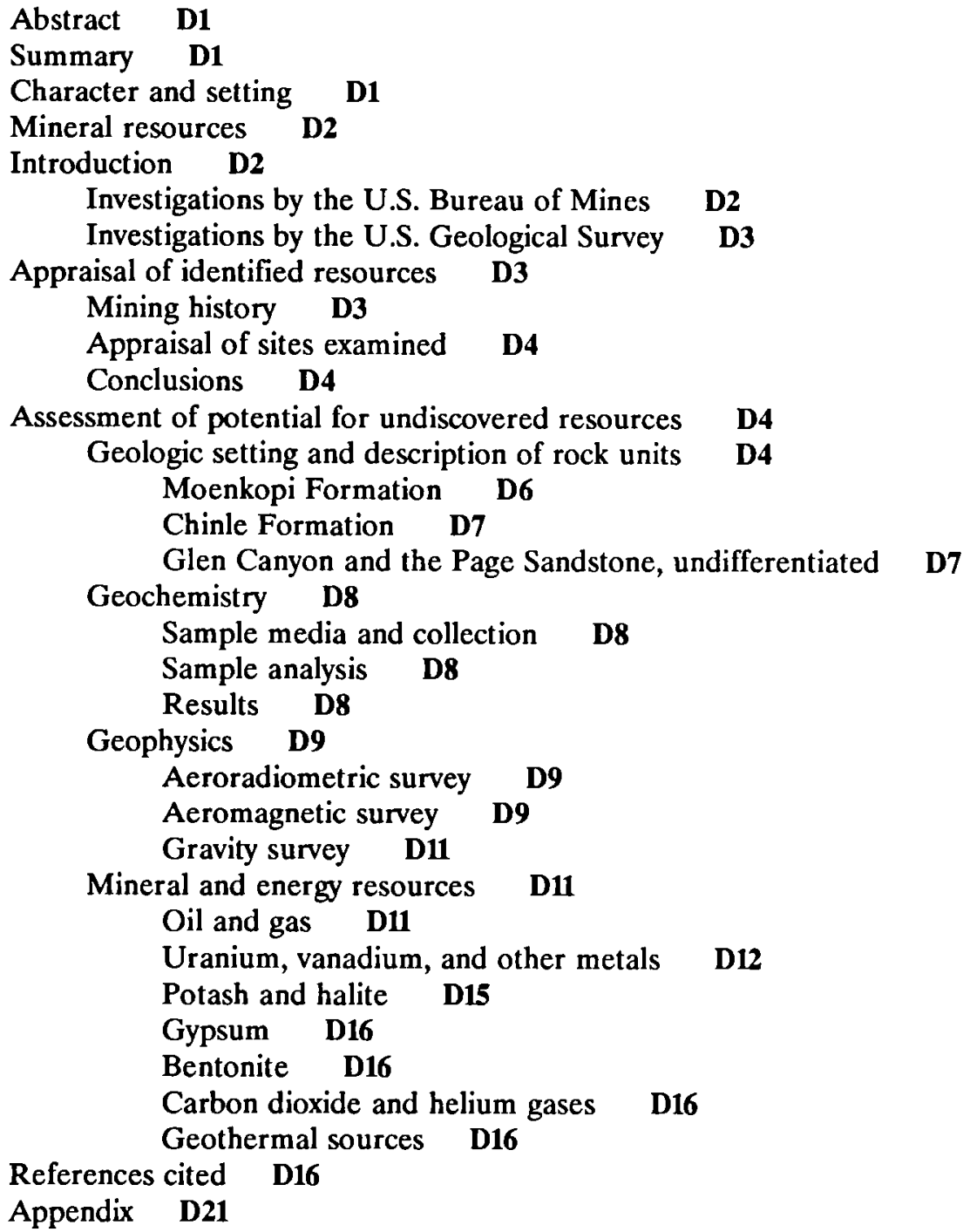

1. Map showing mineral resource potential and generalized geology of the Negro Bill Canyon Wilderness Study Area, Grand County, Utah

\section{FIGURES}

1-5. Maps showing:

1. Approximate boundary and mineral resource potential of the Negro Bill Canyon Wilderness Study Area, Grand County, Utah 
2. Sample localities, mining claims, oil and gas leases and lease applications of the Negro Bill Canyon Wilderness Study Area D5

3. Residual total-intensity aeromagnetics of the Negro Bill Canyon Wilderness Study Area and vicinity, Utah D10

4. Drill holes and inferred structure of the Precambrian surface in the vicinity of the Negro Bill Canyon Wilderness Study Area D13

5. Bouguer anomalies of the Negro Bill Canyon Wilderness Study Area and vicinity, Utah D14

6. Interpretation of the residual gravity anomaly over Moab Valley anticline and over Castle Valley anticline D15 


\title{
Mineral Resources of the Negro Bill Canyon Wilderness Study Area, Grand County, Utah
}

\author{
By Susan Bartsch-Winkler, James E. Case, \\ Harlan N. Barton, and Joseph S. Duval \\ U.S. Geological Survey
}

Michael E. Lane

U.S. Bureau of Mines

\begin{abstract}
The Negro Bill Canyon (UT-060-138) Wilderness Study Area is in southeastern Utah in Grand County southeast of Arches National Monument and covers 7,620 acres. No mineral resources are identified in the study area. Lode mining claims cover the western part of the Negro Bill Canyon Wilderness Study Area; there are no patented claims in the study area. The mineral resource potential for gypsum, potash, halite, and bentonite on the surface and in the subsurface beneath the wilderness study area is high. The energy and mineral resource potential for oil, gas, carbon dioxide, uranium and vanadium on the surface and beneath the wilderness study area is moderate. The potential for helium gas, geothermal sources, and metals other than uranium and vanadium is low.
\end{abstract}

\section{SUMMARY}

\section{Character and Setting}

The U.S. Geological Survey and the U.S. Bureau of Mines, at the request of the U.S. Bureau of Land Management, investigated the Negro Bill Canyon Wilderness Study Area (UT-060-138), which covers 7,620 acres in Grand County, Utah (fig. 1), south of the Colorado River and southeast of Arches National Park. This investigation was completed in September 1988. The area is east of the town of Moab, Utah. Paved access to the area is by U.S. Highway 191 through Moab and Utah State Highway 128 along the

Manuscript approved for publication October 18, 1989.
Colorado River; unpaved roads provide closer access to the area by use of four-wheel-drive vehicles. These include the roads and trails south and north of the study area boundary.

The study area is in a region of very gently folded, generally flat-lying, Mesozoic (see geologic time chart in Appendix) rock sequences including the Triassic Chinle Formation, and the Triassic and Jurassic Glen Canyon Group (the Wingate Sandstone, Kayenta Formation, and Navajo Sandstone) and Jurassic Page Sandstone. The rocks have been folded into very gentle northwest-trending folds of the Grand River-Castle Valley anticline on the east, and the La Sal Creek syncline and the Moab Anticline on the west (all outside the study area boundaries). Capping the highest plateaus in the region is undifferentiated eolian sand and silt of Holocene age, that covers the wilderness study area. The area is one of plateaus and canyons bordering the Colorado River that are arid to semiarid with a mean annual precipitation of 10-15 inches. Most precipitation falls during thunderstorms that produce flash-flooding in the narrow canyons, forcing short-term closure of the unimproved roads in the region.

The most important, and one of the most interesting and complex, geologic features in the State is the Paradox Basin, which has been extensively explored for oil, gas, and potash deposits in the vicinity of the Negro Bill Canyon Wilderness Study Area. The Negro Bill Canyon Wilderness Study Area is located in the southeastern part of the Paradox Basin and adjacent to the Lisbon Valley and Castle Valley salt anticlines and the Texas-Gulf Sulfur mine at Potash.

As part of this study, rock and stream-sediment samples and heavy-mineral panned concentrates of stream sediments were collected for geochemical analysis. The 
results of these analyses indicate no geochemical anomalies within the Negro Bill Canyon Wilderness Study Area.

\section{Mineral Resources}

No mineral resources were identified in the Negro Bill Canyon study area. Sandstone occurs in abundance, but its characteristics make it unsuitable as glass sand; it could possibly be used as fracturing or filtering sand. Sand occurs in the study area but similar deposits are readily available elsewhere closer to possible markets and is not considered a mineral resource.

Because of the probable subsurface occurrence of the Pennsylvanian Paradox Member, a known producer of potash and halite in areas adjacent to the study area, the Negro Bill Canyon Wilderness Study Area has high mineral resource potential for potash and halite in the Paradox at considerable depth beneath the study area. Small localized gypsum beds occur in the Chinle Formation exposed on the northern edge of the study area, and gypsum is typically associated with evaporite deposits, such as the Paradox Member. The mineral resource potential for localized gypsum beds in the Chinle Formation at a depth of less than $1,000 \mathrm{ft}$ and for probable thick beds in the Paradox Formation at greater depth is rated as high. Bentonite is a known constituent of rocks in the lower part of the Chinle Formation in the Colorado Plateau region; therefore, the mineral resource potential for thin dispersed bentonite beds in the lower part of the Chinie Formation exposed in the lower part of Jackass Canyon and at depths of less than $1,000 \mathrm{ft}$ beneath the study area is rated as high. Although no uranium or vanadium minerals were found in the study area, such minerals do occur near Lisbon Valley adjacent to the study area. Thus, the resource potential is moderate for thin discontinuous beds containing uranium and vanadium in the Triassic Chinle and Moenkopi Formations at depths of less than 1,000 $\mathrm{ft}$ and in the Permian Cutler Formation at greater depth. The Negro Bill Canyon Wilderness Study Area is near the Lisbon Valley Field, and similar petroleum target formations occur at depth beneath the study area. However, the necessary structural elements necessary for entrapment of petroleum and its associated byproducts are difficult to detect due to the thick accumulation of Paradox salt. Therefore, the potential for oil, natural gas, and carbon dioxide gas beneath the study area is rated as moderate. Testing of Lisbon Valley Field well for helium gas indicates that trace amounts of helium gas occur in only one of the wells. Thus, the mineral resource potential is low for helium gas. There are no indications of mineralized areas, and geochemical data indicate no concentrations of metals other than uranium and vanadium. Therefore, the mineral resource potential for metals other than uranium and vanadium in the Negro Bill Canyon Wilderness Study Area is low. Lack of thermal springs and stream incision that has exposed Mesozoic rocks in the study area results in a low potential for geothermal sources.

\section{INTRODUCTION}

The U.S. Geological Survey (USGS) and the U.S. Bureau of Mines (USBM) studied 7,620 acres of the Negro Bill Canyon (UT-060-138) Wilderness Study Area at the request of the U.S. Bureau of Land Management (BLM). In this report, the studied area is called the "wilderness study area" or, simply, the "study area."

This report presents an evaluation of the mineral endowment (identified resources and mineral resource potential) of the study area and is the product of several separate studies by the USBM and the USGS. Identified resources are classified according to the system of the U.S. Bureau of Mines and U.S. Geological Survey (1980), which is shown in the Appendix of this report. Identified resources are studied by the USBM. Mineral resource potential is the likelihood of occurrence of undiscovered metals and nonmetals, industrial rocks and minerals, and of undiscovered energy sources (coal, oil, and gas). Mineral and energy resources (except coal) were classified according to the system of Goudarzi (1984) (see also Appendix). Undiscovered resources are studied by the USGS.

The Negro Bill Canyon Wilderness Study Area consists of dissected plateaus and canyons which are rugged, semiarid, and remote. The wilderness study area is within the Colorado Plateaus physiographic province (Thornbury, 1965). On the northwest, it is adjacent to Arches National Park and the Colorado River (fig. 1). The Porcupine Rim is located northeast of the study area. Negro Bill Canyon cuts into the Triassic(?) and Jurassic Navajo and Jurassic Page Sandstones and the Triassic(?) Kayenta Formation; the southeast-trending axis of the Courthouse Syncline transects the area just outside the study area west of Negro Bill Canyon (Hemphill, 1955).

\section{Investigations by the U.S. Bureau of Mines}

Two U.S. Bureau of Mines geologists spent five days conducting a field examination in and within $1 \mathrm{mi}$ of the study area. Surface and accessible underground workings were surveyed by compass and tape, mapped, and sampled.

U.S. Bureau of Mines personnel reviewed literature concerning mining and geology of the region. In addition, U.S. Bureau of Land Management records were reviewed for mining claim information and oil and gas leases and lease applications, which are shown in figure 2 . 

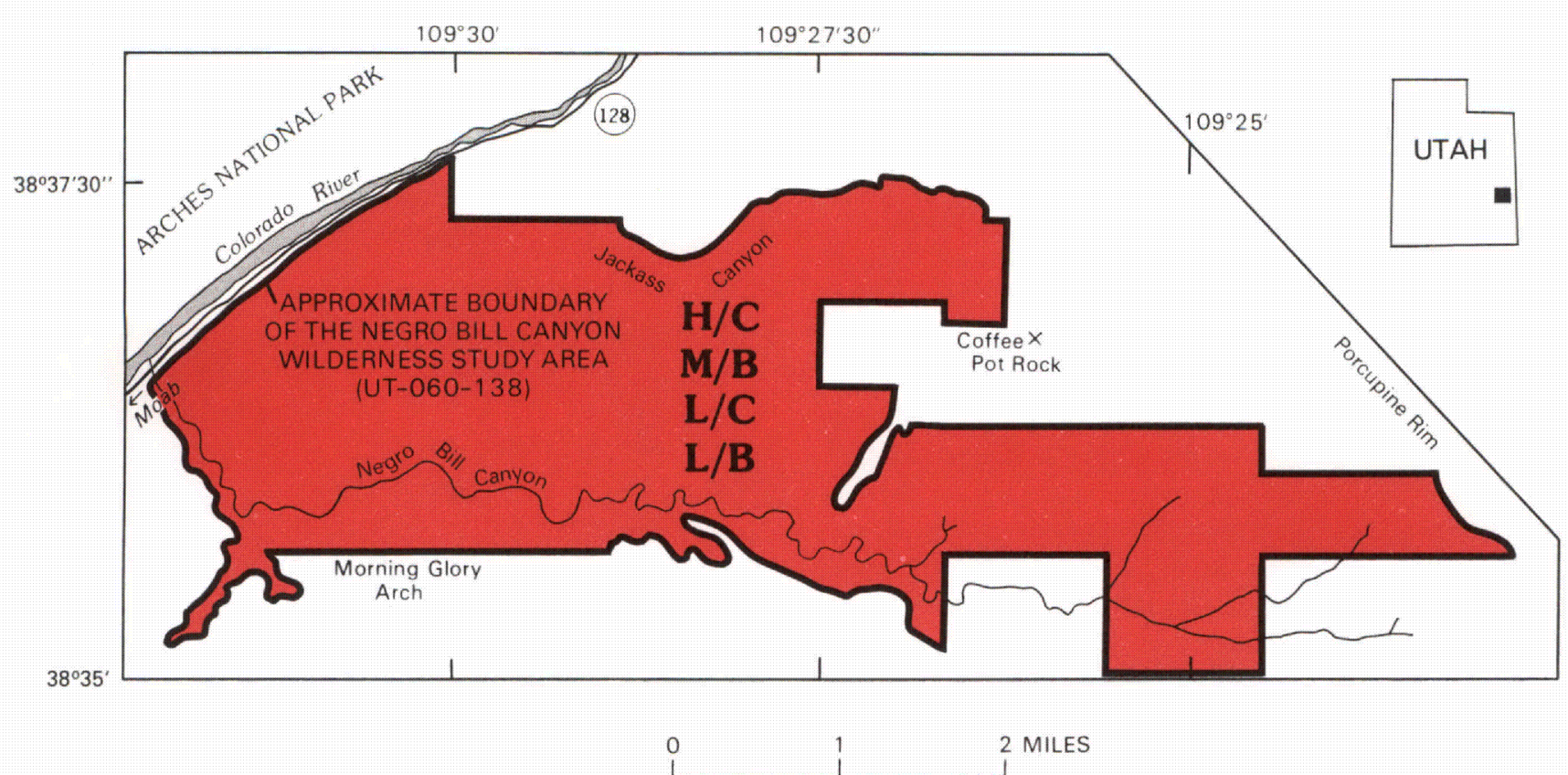

EXPLANATION OF MINERAL RESOURCE POTENTIAL

EXPLANATION OF MINERAL RESOURCE POTENTIAL
$\begin{array}{r}\text { Geologic terrane having high mineral resource potential for small localized beds of gypsum at depths of less than } \\ 1,000 \mathrm{ft} \text { and at greater depth in the Paradox Member of Hermosa Formation beneath the study area, potash } \\ \text { and halite in the Paradox Formation at considerable depth beneath the study area, and for thin, dispersed ben- } \\ \text { tonite beds in the lower part of the Chinle Formation exposed in the lower part of Jackass Canyon and at } \\ \text { depths of less than } 1,000 \mathrm{ft} \text { in the subsurface, with certainty level C } \\ \text { H/C Geologicterrane having moderate energy resource potential for oil, gas, and moderate amounts of carbon dioxide } \\ \text { and for thin, discontinuous beds containing uranium and vanadium in the Chinle and Moenkopi Formations at } \\ \text { depths of less than 1,000 ft and in the Cutler Formation at greater depth, with certainty level B }\end{array}$
M/B Geologic terrane having low mineral resource potential for metals other than uranium and vanadium with cer-
tainty level C
L/C Geologic terrane having low resource potential for helium gas and geothermal sources with certainty level B
L/B Levels of certainty
Data indicate geologic environment and suggest the level of mineral resource potential
B Data indicate geologic environment and give a good indication of the level of mineral resource potential

Figure 1. Approximate boundary and mineral resource potential of the Negro Bill Canyon Wilderness Study Area, Grand County, Utah.

\section{Investigations by the U.S. Geological Survey}

During 1988, personnel from the U.S. Geological Survey conducted independent field investigations using four-wheel-drive vehicles for access to the area; foot traverses were undertaken to accomplish most of the fieldwork. Geologic, geophysical, and geochemical information from these investigations was compiled at 1:24,000 scale.

The geologic information provided in this report was compiled from aerial photographs and field-checked by Susan Bartsch-Winkler in August 1988. Geophysical information is provided by James E. Case, who interpreted the aeromagnetic and gravity data, and Joseph S. Duval, who interpreted the aeroradiometric data. Stream-sediment, heavy-mineral concentrate, and rock samples for geochemical analysis were collected during April and May 1988 by Harlan N. Barton, who interpreted the laboratory analyses of these samples.

APPRAISAL OF IDENTIFIED RESOURCES

\section{By Michael E. Lane U.S. Bureau of Mines}

\section{Mining History}

No mining activity has occurred in the wilderness study area; one adit was found, but there was no evidence 
of economic minerals. The nearest mining district is in the La Sal Mountains about 7 miles southeast of the study area. Lode mining claims cover the western part of the Negro Bill Canyon Wilderness Study Area (pl. 1); there are no patented claims in the wilderness study area.

\section{Appraisal of Sites Examined}

Three samples (NBC1-3) were taken during the field investigation (Lane, 1989). One sandstone sample was analyzed for the characteristics necessary for use as industrial material. The other samples were analyzed by neutron activation for 34 elements including gold and silver. Analyses were conducted by Bondar-Clegg and Company, Lakewood, Colo. No resources were identified and no gold was found in the samples (Lane, 1989).

Eolian sand deposits are abundant in the study area (Baker, 1933; Richmond, 1962), but are not considered to be economic. Similar sand occurs elsewhere closer to possible markets.

The sandstone sample taken in the wilderness study area is protoquartzite containing 75-95 percent $\mathrm{SiO}_{2}$. This sandstone is not suitable as glass sand because the $\mathrm{SiO}_{2}$ content ( 86.8 percent) is too low, the $\mathrm{FeO}_{2}$ content ( 0.68 percent) is too high, and the $\mathrm{Al}_{2} \mathrm{O}_{3}$ content (3.09 percent) is too high (Bates, 1960; Lane, 1989). Also, it is not suitable as foundry sand because of low $\mathrm{SiO}_{2}$ content (86.8 percent) (Coope and Harben, 1977).

The sandstone could be suitable as fracturing or filtering sand; however, characteristics for these uses are very variable. The sandstone is unlikely to be developed because similar deposits occur nearer to possible markets.

Oil and gas leases cover a very small part of the study area (fig. 2). The wilderness study area was investigated for uranium during the uranium boom of the 1950 's; no uranium occurrences were found. No geothermal resources are known to exist in the wilderness study area.

\section{Conclusions}

No mineral resources were identified in the Negro Bill Canyon study area. Sandstone occurs in abundance, but its characteristics make it unsuitable as glass sand; it could possibly be used as fracturing or filtering sand. It is unlikely the sandstone will be developed because similar deposits occur nearer to possible markets. Sand occurs in the study area but similar material is readily available elsewhere closer to possible markets and is not considered a mineral resource.

\section{ASSESSMENT OF POTENTIAL FOR UNDISCOVERED RESOURCES}

\author{
By Susan Bartsch-Winkler, \\ James E. Case, Harlan N. Barton, and \\ Joseph S. Duval \\ U.S. Geological Survey
}

\section{Geologic Setting and Description of Rock Units}

The first account of the geology in the area was conducted by Newberry (1876), as a member of the Macomb expedition to the Green and Colorado Rivers junction in 1859. Various other expeditions were conducted in the region in subsequent years (for example, Powell, 1875; Peale, 1877; Dutton, 1880, 1882a, b; Cross, 1907; Lee, 1918); Baker (1933) wrote the first comprehensive report on the geology of the area in his assessment of the oil and gas possibilities of the Moab District that was a precursor for later, more detailed studies cited herein.

The sedimentary rock sequences that crop out in the region of the Negro Bill Canyon Wilderness Study Area range in age from Triassic to Jurassic, and include the Moenkopi and Chinle Formations, the Glen Canyon Group, and Page Sandstone (pl. 1). The Glen Canyon Group includes, in ascending order, the Wingate Sandstone, Kayenta Formation, and the Navajo Sandstone. Distribution of the Triassic units is controlled by underlying Pennsylvanian-age salt (Paradox Member); the lithology, thickness, and lateral extent of Triassic rock units is variable depending on the movement of underlying salt. Triassic rock units in the vicinity of the Negro Bill Canyon study area range in thickness from 1,250 to 2,500 $\mathrm{ft}$ (O'Sullivan and MacLachlan, 1975).

The Paradox basin probably formed in Late Mississippian and Early Pennsylvanian time, when the first major orogeny raised the Uncompahgre Highland northeast of the basin and was accompanied by subsidence in the Paradox basin (Mahoney and Kunkel, 1963). The deepest part of the Paradox basin lies close to the Uncompahgre front (Case and Joesting, 1972). During this tectonic episode, the Mississippian and older structures were formed, and they probably retained their identity during subsequent episodes, and were altered only by faulting (Quigley, 1963). A thick evaporite section of Pennsylvanian age unconformably overlies Mississippian and older rocks in the basin; these salt deposits are relatively mobile, and there is a general lack of conformity of post-Pennsylvanian strata with the 


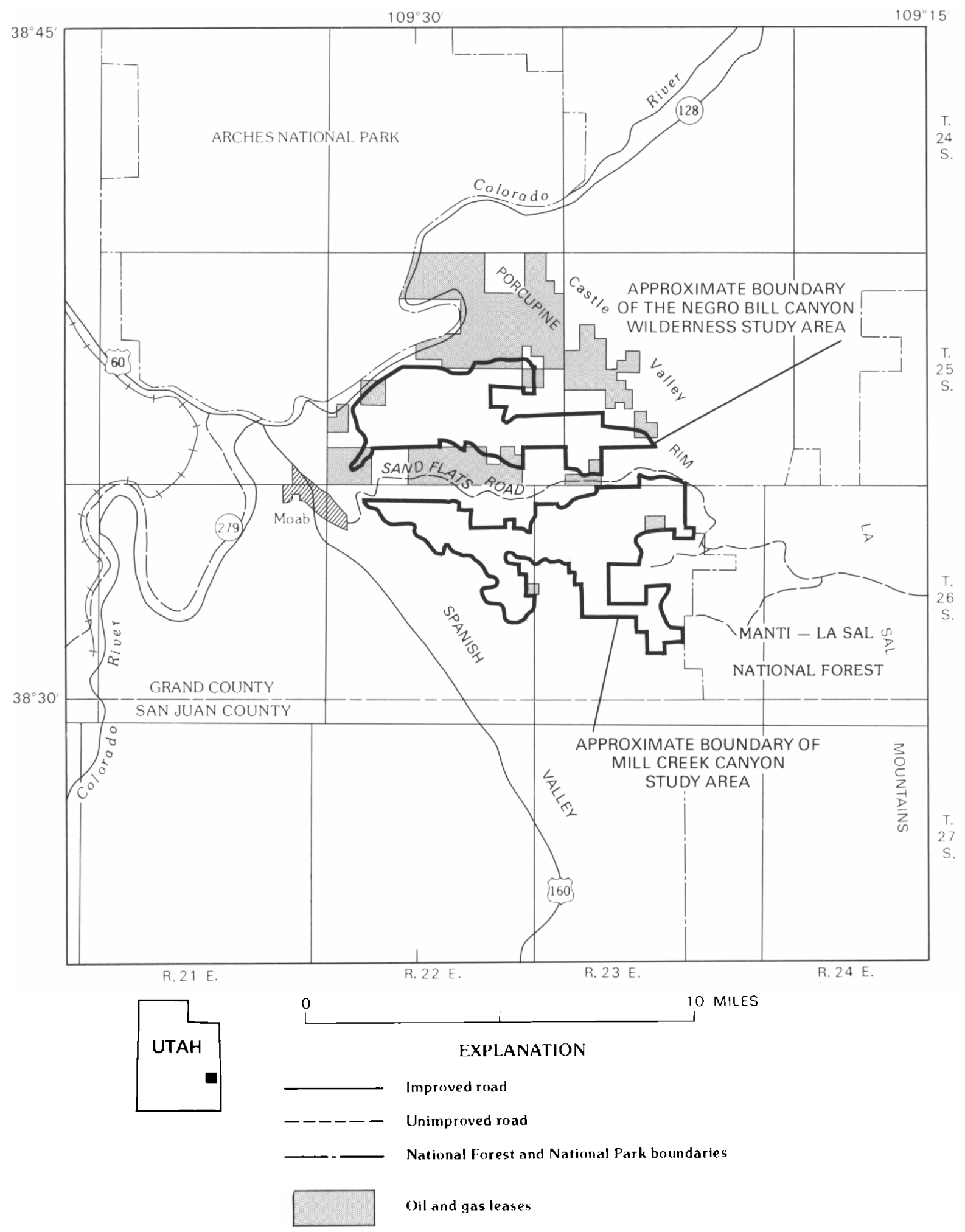

Figure 2. Map showing sample localities, mining claims, oil and gas leases and lease applications of the Negro Bill Canyon Wilderness Study Area. 
structural trend of pre-Pennsylvanian deposits. Seismology indicates the presence of Paleozoic structures and structural trends that have no recognizable surface expression (Quigley, 1963). The structural trend of the older deposits is probably more closely allied to the basement structural trend (Quigley, 1963). Gravity data show that certain lineaments in the Paradox basin have a northwest-southeast trend that may reflect post-Pennsylvanian tectonic origins; basement rocks apparently have a more east-west orientation (Quigley, 1963). According to Baars and Molenaar (1971), the numerous elongate valleys of the Paradox fold and fault belt were formed when thick masses of salt flowed against buttresses formed by basement faulting aligned, in general, with the Uncompahgre uplift (Case and Joesting, 1972). Subsequent solution of the tops of diapiric salt masses by groundwater caused collapse of overlying units into the crests of the salt diapirs, forming elongate valleys.

As determined by exploratory drilling in the region, the regional subsurface post-Mississippian sequence includes the Pennsylvanian Molas and Hermosa Formations and the Permian Rico and Cutler Formations (Papulak, 1963; Baars and Seager, 1970; Baars, 1975; Bradley, 1975). The Hermosa can be divided into three parts. Some authors assign group rank to the Hermosa and designate (ascending order) the Pinkerton Trail, Paradox, and Honaker Trail Formations in it. Other authors (and this report) assign Hermosa to formation rank and designate its divisions the lower member, Paradox Member, and upper member. The area is underlain by approximately $3,500 \mathrm{ft}$ of Paradox salt (Papulak, 1963, fig. 137, sec. B-B', Gibson Dome; Baars and Molenaar, 1971). According to Papulak (1963), the Paradox contains 29 halite beds separated by shale, siltstone, anhydrite, dolomite, and sandstone. The upper part of the Paradox, consisting of biostromal limestone and dolomite, is an oil-producing unit in the southern part of the Paradox basin (Papulak, 1963). Apparently there is an erratic distribution of oil and gas in the Paradox rocks, and this is a characteristic of fracture reservoirs (Papulak, 1963). Probably, fracturing and faulting are necessary to accumulate oil and gas in this region (Papulak, 1963; Mahoney and Kunkel, 1963). The Mississippian and older sequence includes the Lower Mississippian limestone (called variously the Leadville or Redwall Limestone), Devonian Ouray Limestone and Elbert and Aneth Formations, Cambrian Ophir Shale and Ignacio Quartzite, and Precambrian igneous and metamorphic basement rocks (Baars and Molenaar, 1971; Bradley, 1975).

The following descriptions of the Moenkopi and Chinle Formations are after O'Sullivan and MacLachlan (1975), except where referenced.

\section{Moenkopi Formation}

The Lower and Middle(?) Triassic Moenkopi Formation regionally overlies the Permian Cutler Formation at the $\mathbf{k}-1$ unconformity of Pipiringos and O'Sullivan (1975), though the underlying rocks and the unconformity are not exposed in the Negro Bill Canyon area. The Moenkopi Formation is a low-energy marine (tidal flat and fluvial) deposit, containing parallel and interference ripple marks, ripple crossbeds, desiccation features (mudcracks and salt casts), and minor gypsum. The unit is $700 \mathrm{ft}$ thick in the northwestern part of the Paradox basin, but thins to nil on the southeastern side of the Paradox basin. In some parts of the basin the thickness is highly variable due to salt flowage and locally can attain thicknesses in excess of 2,500 $\mathrm{ft}$ (Molenaar, 1981).

The Moenkopi Formation in the eastern part of the Negro Bill Canyon Wilderness Study Area is subdivided into the Tenderfoot, Ali Baba, Sewemup, and Pariott Members; the formation is not subdivided near the town of Moab on the western border of the study area. At Moab, the thickness of the formation ranges from 0 to $900 \mathrm{ft}$.

The Tenderfoot Member consists of lenticular beds of reddish-brown, medium- to coarse-grained, horizontal and cross-stratified conglomerate, arkosic sandstone, and homogeneous reddish-brown, thin- to thick-bedded micaceous siltstone, platy, slabby reddishbrown and grayish-red, horizontally laminated and rippled siltstone, and irregular gypsum beds that are as much as $7 \mathrm{ft}$ thick locally. The thickness of the Tenderfoot Member in the Salt Anticline area ranges from 9 to $290 \mathrm{ft}$; it is thickest at the margins of the salt intrusions.

The Ali Baba Member rests unconformably on the Tenderfoot Member, but its upper contact is gradational into the overlying Sewemup Member. The Ali Baba Member consists of a ledge-forming red-brown to purple conglomeratic and arkosic sandstone, interbeds of redbrown to chocolate-brown siltstone, and thin beds of fine- to coarse-grained sandstone. The Ali Baba Member is as much as $224 \mathrm{ft}$ thick northeast of Moab. The unit is coarsest near the Uncompahgre uplift and finer grained and better sorted to the southwest.

The Sewemup Member is variable in thickness, ranging from 170 to $379 \mathrm{ft}$. The unit is overlain by the Chinle Formation regionally, but in the vicinity of the Negro Bill Canyon Wilderness Study Area, it is overlain by the Pariott Member. The Sewemup is a micaceous reddish-brown to grayish-red siltstone interbedded with light-brown very fine grained to fine-grained sandstone. Thin beds of coarser sandstone occur throughout the unit. Gypsum occurs as veinlets or as cement; near the top of the unit, nodular gypsum is present. 
The Pariott Member is named for the type section on Pariott Mesa northeast of Moab and about $4 \mathrm{mi}$ north of the east end of the Negro Bill Canyon Wilderness Study Area on the northeast side of Castle Valley. It is $135 \mathrm{ft}$ thick at the type section. The lower contact with the Sewemup Member is gradational, but the upper contact is unconformable with the Chinle Formation. The unit consists of varicolored reddish-brown to purplish-brown sandstone, chocolate-brown, red, and orange mudstone, siltstone, and shale. Typically, it is ripple marked micaceous sandstone, some of which is conglomeratic.

\section{Chinle Formation}

The Chinle Formation is predominantly a fluvial sequence deposited in a large basin that covered parts of Arizona, Utah, Colorado, and New Mexico. Exposures are widespread, but individual members of the formation interfinger and have distinct sedimentological character (Stewart and others, 1972). The Chinle Formation near Moab is equivalent to the upper part of the formation as described at the type locality at Chinle, Ariz. At Moab, the Chinle consists of, in ascending order, the sandstone member, claystone member, the Black Ledge member, and the siltstone member (Baars and Molenaar, 1971). The Chinle contains minor amounts of gypsum and is bentonitic in the lower part and nonbentonitic in the upper part (Baars and Molenaar, 1971). Both the base and the top of the Chinle Formation are marked by unconformities. Northeast of Moab, however, the unconformity is a slight angular discordance (Dane, 1935, p. 63), and near Moab the Chinle rests on the Hermosa Formation of Pennsylvanian age (Baker, 1933, p. 36-37). It is likely that movement of salt in the underlying rocks contributed to this disconformable contact at the base of the Chinle.

The contact between the Moenkopi and Chinle Formations is exposed along the Colorado River on Utah Highway 128 east of Moab (fig. 1; pl. 1). This contact displays an unusual mottling oriented generally vertical to Chinle bedding planes. The features, usually white to light tan, are most common in a purple and white mottled zone in silicified coarse-grained sandstone and siltstone at the base of the Chinle. In an earlier work, AbdelGawad and Kerr (1963) attributed these features to hydrothermal alteration by springs; the hydrothermal activity was supposedly associated with uranium mineralization. However, such structures have been interpreted as fossil aestivation burrows of the lungfish (Gnathorhiza) (Dubiel and others, 1987a, b), though this hypothesis is disputed by McAllister (1987) and has been modified to include possible burrow construction by a decapod crustacean (Hasiotis and Mitchell, 1989).

The sandstone member, present near Moab, is at least $200 \mathrm{ft}$ thick, and may be as much as $800 \mathrm{ft}$ thick. The unit consists of light-gray, mottled reddish-brown and purple, friable coarse sandstone that is crossbedded and locally contains pebbles.

The claystone member ranges from 40 to $100 \mathrm{ft}$ thick; it rests either on the sandstone member or, where that is absent, on the Moenkopi Formation. The member consists of purple, gray, yellow, greenish-gray, grayishred, and reddish-brown claystone and siltstone, and locally contains abundant limestone nodules. The unit contains bentonite clay and minor fine- to coarse-grained red and gray sandstone.

The Black Ledge is $123 \mathrm{ft}$ thick near Moab. The unit is commonly stained by desert varnish making it easily recognizable, and consists of pale-red, reddishbrown, and gray, very fine grained sandstone. The unit is typically crossbedded. Minor occurrences of conglomeratic sandstone and lenticular beds of thin greenish-gray and reddish-brown siltstone and shale are present.

The siltstone member is variable in thickness, ranging from 100 to $200 \mathrm{ft}$ near Moab. It is composed of a reddish-brown to reddish-orange, and spotted greenish-gray coarse-grained siltstone and fine-grained sandstone. Pebbles occur locally. The member is overlain unconformably by the Glen Canyon Group. Glen Canyon Group and the Page Sandstone, Undifferentiated

\section{Glen Canyon and the \\ Page Sandstone, Undifferentiated}

Continental rocks of the Glen Canyon Group contain sparse fossils, and the age assignment of the group is questionable and based, in part, on stratigraphic relations. In this report, the Wingate Sandstone is considered to be Late Triassic, the Kayenta Formation to be Late Triassic(?), and the Navajo Sandstone to be Triassic(?) and Jurassic (Lewis and others, 1961). The Page Sandstone is Middle Jurassic (Pipiringos and O'Sullivan, 1975). Recent evidence (Peterson and Pipiringos, 1979) indicates that the group may be only Early Jurassic in age; however, for this report the older accepted age of Triassic(?) and Jurassic is used. The Wingate Sandstone and the Navajo and Page Sandstones are predominantly thick eolian units, and the Kayenta Formation is predominantly a fluvial unit.

The Wingate Sandstone is a buff to tan, pink, and dark-gray, massive to crossbedded, quartzose, very fine to fine-grained sandstone with a few thin lenses of limestone and beds of calcareous sandstone. The unit is distinguished by a reddish stain and forms vertical cliffs. Vertical joints and their attendant talus deposits are abundant with this unit. It ranges from about 240 to 370 $\mathrm{ft}$ thick. The J-O unconformity of Pipiringos and O'Sullivan (1975) separates the Wingate Sandstone from the underlying Chinle Formation. 
The Kayenta Formation is a lavender, red-brown, and pale-red, thin- to medium-bedded, irregularly bedded and crossbedded, fine- to coarse-grained sandstone; subordinate interbeds of red and green mudstone, siltstone, conglomerate, and lacustrine limestone also occur. It generally forms broken cliffs in the lower part and shaly slopes in the upper part, but in some places the Kayenta forms a continuous cliff between the Wingate and Navajo Sandstones. Sedimentological evidence suggests that the Kayenta Formation is predominantly a fluvial deposit (Poole, 1961). The unit is conformable, and intertongues with the overlying Navajo Sandstone and the underlying Wingate Sandstone. The Kayenta Formation is $100-250 \mathrm{ft}$ thick.

The Navajo Sandstone, due to strong jointing, is characterized by a checkerboard or elephant-hide pattern of erosion. It typically forms sheer cliffs and rounded knolls and domes, mostly without vegetation. The Navajo Sandstone is a very fine to medium-grained, white to buff-colored sandstone (with scattered pebbles interspersed) that is dominantly eolian and strikingly crossbedded to massive. Rare lacustrine (lake deposited) interbeds of shale, dolomite, and limestone, some containing chert pebbles (McKnight, 1940), also occur in this unit, but none exceed $10 \mathrm{ft}$ in thickness; most are less than $3 \mathrm{ft}$ thick (Doelling, 1975). According to McKnight (1940), in the area south of Courthouse Spring $12 \mathrm{mi}$ northwest of Moab, the upper part of the Navajo contains limestone beds and beds with angular chert; these beds may be the unconformity recognized by Pipiringos and O'Sullivan (1975) - the J-2 unconformity-separating the Navajo from the overlying Page Sandstone. The Page Sandstone, which is identical to the Navajo Sandstone, was not recognized in the field, its existence within the study area is unknown, and has been mapped with the Glen Canyon Group in this report. The Navajo and Page Sandstones are generally interpreted as predominantly wind-blown deposits that total about 200-400 ft thick in the vicinity of Moab, that were probably deposited in an interior desert environment (Molenaar, 1981; 1987), though other interpretations on its environment of deposition have been presented (Stanley and others, 1971; Freeman and Visher, 1975).

The Glen Canyon Group is locally altered and mineralized at places on the Colorado Plateau. The group also is an important potential reservoir for water, oil, gas, liquid bitumen, carbon dioxide, geothermal sources, and helium (O'Sullivan and MacLachlan, 1975).

\section{Geochemistry}

\section{Sample Media and Collection}

Minus-80-mesh stream sediments, heavy-mineral panned concentrates derived from stream sediments, and rocks were selected as sample media for the reconnaissance geochemical survey of the Negro Bill Canyon Wilderness Study Area.

Stream-sediment samples represent a composite of rock and soil exposed in the drainage basin upstream. Their analysis provides information that helps identify those basins containing unusually high concentrations of elements that may be related to mineral occurrences.

Chemical analysis of heavy minerals concentrated from stream sediments provides information about the chemistry of certain high-density, resistant minerals eroded from the drainage basin upstream. The removal of most of the rock-forming silicates, clays, and organic material permits the determination of some elements in the concentrate that are often not detectable in bulk stream sediments by the analysis methods available. Some of these elements can be constituents of minerals related to ore-forming processes rather than rockforming ones.

Four rock samples were collected to provide information on geochemical background values and to detect any possible mineralization. Visibly altered and mineralized samples which might disclose suites of elements associated with mineralization were not found.

Bulk stream-sediment and heavy-mineralconcentrate samples were collected from active alluvium from 14 first- or second-order ephemeral streams with drainage basins ranging from 0.2 to 2.0 square miles. Two sample sites were located on the upper reaches of Negro Bill Canyon and others were located on tributary canyons downstream. Additionally, three canyons which drain directly into the Colorado River in the northern part of the study area were sampled.

\section{Sample Analysis}

Stream-sediment, heavy-mineral-concentrate, and rock samples were all analyzed using a semiquantitative emission spectrographic method for the following 37 elements: iron, magnesium, calcium, sodium, phosphorus, titanium, manganese, silver, arsenic, gold, boron, barium, beryllium, bismuth, cadmium, cobalt, chromium, copper, gallium, germanium, lanthanum, molybdenum, niobium, nickel, lead, antimony, scandium, tin, strontium, vanadium, thorium, tungsten, yttrium, zinc, zirconium, palladium, and platinum.

In addition, stream-sediment and rock samples were analyzed for arsenic, antimony, bismuth, cadmium, gold, uranium, thorium, and zinc by specific chemical and instrumental methods.

\section{Results}

The study area is overlain by a thick sequence of Triassic to Jurassic sedimentary rocks and their barren 
nature relative to any near-surface metallic mineralization is disclosed by the geochemical study (Bullock and others, 1989). No anomalous values were detected in any of the samples.

\section{Geophysics}

Reconnaissance geophysical data are typically not used for the detection of mineral deposits, but such information aids in providing a three-dimensional geologic framework that serves to guide exploration. Geophysical information available for the Negro Bill Canyon study area includes aeroradiometric, aeromagnetic, and gravity surveys. Seismic reflection data would be useful for resource evaluation but is not in the public domain.

\section{Aeroradiometric Survey}

Aerial gamma-ray spectroscopy is utilized to determine the near-surface concentrations of potassium (in percent) and uranium and thorium (in parts per million); because uranium and thorium measurements utilize radioactive daughter nuclei that are chemically distinct from the parent nuclei, the uranium and thorium data are described as equivalent concentrations. For a typical aerial survey, each measurement represents average concentrations for a surface area on the order of 646,000 square feet to an average depth of about $1 \mathrm{ft}$. From 1975 to 1983, the U.S. Department of Energy contracted for aerial gamma-ray surveys that covered most of the United States, including Utah, at flight-line

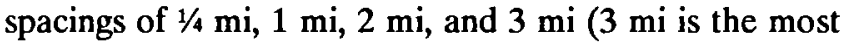
common spacing used in Utah). Because of the wide flight-line spacing, the survey is only suitable for producing a regional-scale map. As part of the state mapping project of Utah, data were compiled and processed to produce a series of 1:1,000,000-scale maps, including composite-color maps of the type described by Duval (1983). These maps were examined to estimate the concentrations of potassium, thorium, and uranium, for each wilderness study area in the State. The definition of an anomaly requires that the element concentration, as well as its ratios to the other two elements, all be high values within the context of the map. For the Negro Bill Canyon Wilderness Study Area, the overall radioactivity is low. Concentrations are 1.4-2.0 percent potassium; 0.5-1.5 ppm (parts per million) equivalent uranium; and 1-4 ppm equivalent thorium. There are no gamma-ray anomalies within or adjacent to the study areas.

\section{Aeromagnetic Survey}

Aeromagnetic surveys over the Negro Bill Canyon study area and vicinity were flown east-west at two different flight elevations: the eastern part was flown at an elevation of about $12,500 \mathrm{ft}$, flight-line spacing about $1 \mathrm{mi}$ (Case and others, 1963). The western part was flown at an elevation of about $8,500 \mathrm{ft}$, flight line spacing about $1 \mathrm{mi}$ (Joesting and others, 1966). Subsequently, the magnetic data in the western part were continued upward to $12,500 \mathrm{ft}$ (Hildenbrand and Kucks, 1983) (fig. 3).

Anomalies on the map by Joesting and others (1966), flown at $8,500 \mathrm{ft}$, diminish somewhat in amplitude when extended upward subsequently to 12,500 ft (Hildenbrand and Kucks, 1983), but they retain their shapes. The Phanerozoic sedimentary sequence in the region is about $14,000-15,000 \mathrm{ft}$ thick. This emphasizes the intrabasement (Precambrian) origin for most of the aeromagnetic anomalies in the region, although Cretaceous-Tertiary intrusive sources cannot be discounted. High-amplitude, steep-gradient anomalies in the eastern part of figure 3 are produced by laccolithic intrusions of the La Sal Mountains (Late CretaceousEarly Tertiary). No sources of magnetic anomalies in the Phanerozoic sedimentary sequence in the region have been identified.

From the combined data from deep drill holes and depth estimates from the magnetic data, schematic contours of the post-Precambrian surface have been prepared (Case and Joesting, 1972; fig. 4). For example, just south of the study area a drill hole bottomed in Devonian strata at $5,882 \mathrm{ft}$ below sea level; on the northeast flank of Castle Valley anticline, a drill hole penetrated about $3,000 \mathrm{ft}$ of evaporites and bottomed in Cambrian strata at about $6,825 \mathrm{ft}$ below sea level, and farther northeast another drill hole bottomed in Cambrian strata at $9,377 \mathrm{ft}$ below sea level. Because the deep Mississippian-Cambrian stratigraphy is relatively well known from many drill holes to the west and south, it is possible to estimate the elevation of the Precambrian surface. Thickness of Mississippian-Cambrian strata in the Lisbon Valley area, southeast of the study area, ranges between 1,675-1,855 $\mathrm{ft}$. In the study area, the basement is probably $8,000-9,000 \mathrm{ft}$ below sea level.

The magnetic field over the study area itself is somewhat uniform, based on data from one flight line; a south-plunging positive nose occurs over the eastern part of the study area and a negative open re-entrant occupies the western part (fig. 3). Values increase northward by 20-30 gammas across the study area. These magnetic features are probably related to a much larger closed magnetic high located about $10 \mathrm{mi}$ northeast of the study area. This high is undoubtedly produced by a very deep $(10,000 \mathrm{ft}$ below sea level, or more) magnetic body within the Precambrian basement. 


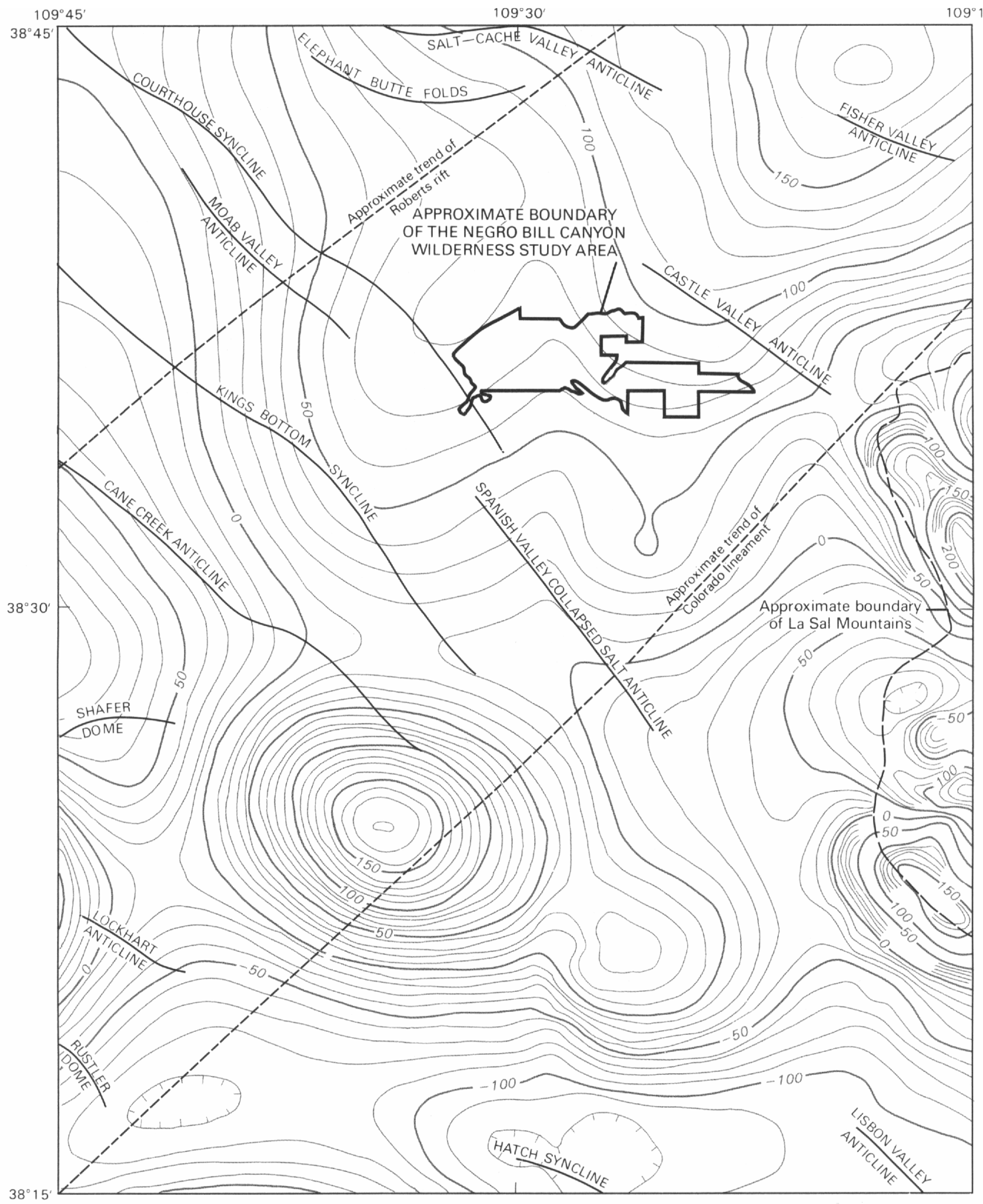

0

5

10

15 MILES

Figure 3. Map showing residual total-intensity aeromagnetic of the Negro Bill Canyon Wilderness Study Area and vicinity, Utah. Contour interval 10 gammas. Hachures show closed areas of lower magnetic intensity. Original magnetic data continued upward to an elevation of 12,500 ft. From Hildenbrand and Kucks (1983), and Patterson and others (1988). 


\section{Gravity Survey}

Only one gravity station was established within the study area, but numerous stations just north and south of the area provide control on the regional gravity anomaly field. The gravity data were reduced for a Bouguer reduction density of $2.5 \mathrm{~g} / \mathrm{cm}^{3}$; terrain corrections were calculated to a distance of $4.1 \mathrm{mi}$ from the station or farther. Distance of terrain corrections depended on terrain setting of each station. Corrections for stations at higher elevation were calculated to greater distances. Details are provided in the reports by Case and others (1963), Joesting and others (1966), and Hildenbrand and Kucks (1983). Briefly, the study area is at the site of a relative gravity high between the large northwesttrending negative anomalies associated with the Moab Valley-Spanish Valley and Castle Valley salt anticlines (fig. 5).

Two 2-dimensional gravity models have been constructed for anomaly profiles near the study area (fig. 6). One (fig. 6A) is across the Moab-Spanish Valley salt anticline just northwest of the study area, and the other (fig. $6 B$ ) is across the Castle Valley anticline (Case and Joesting, 1972). A third schematic model (fig. 5; $E-E^{\prime}$ ) has been calculated for a profile across the Spanish Valley anticline and the Mill Creek Study area, just southwest of the Negro Bill Canyon area (Diggles and others, written commun.). The salt core of the MoabSpanish Valley anticline has structural relief of about $6,000-9,000 \mathrm{ft}$ on the models, assuming a mean density contrast of $-0.35 \mathrm{~g} / \mathrm{cm}^{3}$ between the salt and the adjacent strata. Subsequent well data indicate that the amplitude of the fold varies from about 7,000-9,000 ft. The amplitude of the salt core of the Castle Valley anticline is about $8,000 \mathrm{ft}$, assuming a mean density contrast of -0.3 $\mathrm{g} / \mathrm{cm}^{3}$. Whether evaporites are present beneath the wilderness study area depends on location with respect to the Castle Valley and the Moab-Valley-Spanish Valley anticlines. Salt may have flowed completely into one or both anticlines. If not, then the potential for potassium is high in the study area.

\section{Mineral and Energy Resources}

\section{Oil and Gas}

The search for oil and gas began in the region in the 1920 's, but a commercial well was not established until the late 1950's in Mississippian rocks. Since that time, petroleum has been extracted from the Pennsylvanian Hermosa Formation, from the Paradox Member and the upper member, as well as from Mississippian and Devonian rocks caught up within and underlying the Paradox. According to Papulak (1963), as of 1963 as many as 60 wells had been completed with nearly half having oil and (or) gas shows, but only four discoveries. He attributes this to difficulties encountered in drilling into salt deposits. Also, structures below the Paradox are difficult to interpret using geophysical methods because they are masked by the thick accumulation of salt (Quigley, 1963). There is a lack of structural conformity between rocks above and below the salt deposits; the anticlinal structures on the surface produced by salt flowage at depth are commonly underlain by synclines or low areas in pre-salt target formations. In fact, the pre-salt structures probably bear a closer affinity to those in the basement rocks than to those on the surface (Quigley, 1963). Therefore, geophysical interpretation of basement structures is of great importance in determining Paleozoic structures that might contain hydrocarbons (Quigley, 1963). Regionally there are six structural configurations that result from periods of uplift, folding, faulting, salt flowage, and subsidence. These are (1) units above the Cutler, (2) units from the top of the Cutler to the unconformity within the Cutler, (3) units from the unconformity to the uppermost Paradox salt, (4) the middle and lower Paradox salt, (5) pre-salt Paleozoic strata, and (6) pre-Cambrian crystalline basement rocks (Parker, 1981). Of these, the primary targets for oil and gas accumulation are structural configurations 3,4 , and 5 .

Shows of oil, and flammable and non-flammable gas have been encountered primarily in Mississippian rocks lying beneath the salt deposits. Most production in east-central Utah comes from reservoirs in Devonian, Mississippian, and Pennsylvanian rocks, with minor production from Triassic and Jurassic rocks (Spencer, 1975). In the Lisbon Valley area about $40 \mathrm{mi}$ southeast of Moab, a salt anticline has been faulted, but not breached. The surface fault has about $4,000 \mathrm{ft}$ of vertical displacement and dissipates within the underlying salt; it does not cut pre-salt rocks (Smith and Prather, 1981). A subsurface fault in Mississippian rocks is present several miles from the surface fault and is not parallel to it; this underlying fault also dissipates in the salt (Smith and Prather, 1981). Major oil production has taken place from porous zones in Mississippian dolomite beds where the petroleum has been trapped by the faulted anticline (Parker, 1981). The oil-producing Mississippian rocks are totally encased in Paradox salt because of salt flowage (Smith and Prather, 1981). Minor oil production in the Lisbon Valley Field area also occurs in limestone and dolomite of the Devonian Ouray Limestone, McCracken Sandstone Member of the Elbert Formation, and from a clastic zone in the Pennsylvanian Paradox (Parker, 1981). Two additional undeveloped Mississippian dolomite gas fields are near the Lisbon Valley Field (Big Indian and Little Valley areas) and one undeveloped oil and gas field is in the sandstone of the Honaker Trail Formation or upper Member of the Hermosa (Pennsylvanian) in the 
Litte Valley area northeast of the Mississippian accumulation (Parker, 1981). Much of the unrecoverable oil and gas occurs in heavy exotic brines and halite (Smith, 1981).

The Negro Bill Canyon Wilderness Study Area is near the Lisbon Valley Field and similar petroleum target formations occur at depth beneath the study area, but necessary structural elements are difficult to detect by geophysical methods beneath the thick accumulation of Paradox salt. The study area has been assessed for oil and gas potential by Molenaar and Sandburg (1983) who rated it as moderate. We also rate the energy resource potential for oil and gas in the Negro Bill Canyon Wilderness Study Area as moderate, with certainty level $\mathrm{B}$.

\section{Uranium, Vanadium, and Other Metals}

Sandstone-hosted uranium deposits are associated with generally flat-bedded feldspathic or tuffaceous sandstone of Devonian or younger age in a stable platform or foreland interior basin setting (TurnerPeterson and Hodges, 1986). According to TurnerPeterson and Hodges (1986), the microcrystalline uranium oxides and silicate ores form during postdepositional alteration of fine- to medium-grained permeable sandstone beds within shale and mudstone sequences, and later are redistributed by ground water; some uranium oxides are concentrated at an oxidation/reduction boundary. Further, the interbedded mudstone or shale provides the source for ore-bearing fluids; carbonaceous material typically reacts with these fluids to precipitate the uranium. Fluvial channels, braided stream deposits, continental-basin margins, and stable coastal plains are the most characteristic settings for uranium deposits.

In the late 1800 's, uranium and vanadium ore was discovered in the Jurassic Salt Wash Member of the Morrison Formation southeast of Moab (Chenoweth, 1975). In 1952, significant uranium deposits were found in the Moss Back Member of the Chinle Formation at Lisbon Valley. Since that time, small uranium deposits have been found in the Permian Cutler Formation west of Lisbon Valley (Chenoweth, 1975). With only a few exceptions, uranium occurs at or near the unconformable contact of the Chinle Formation with the underlying rocks (typically the Moenkopi Formation). The principal ore mineral is uraninite, with small amounts of coffinite and the vanadium minerals montroseite, doloresite, and vanadium clay and (or) hydromica (Chenoweth, 1975). The ore-bearing rock of the Chinle Formation is gray, poorly sorted, fine- to coarse-grained, calcareous, arkosic, quartzose sandstone, containing minor mudstone and limestone pebbles and mudstone and siltstone lenses, and is typically associated with organic material (Che- noweth, 1975). The ore-bearing units in the Cutler Formation are composed of alternating beds of mudstone, calcareous siltstone, and arkosic sandstone of fluvial-distributary origin (Chenoweth, 1975; Campbcll, 1981). Ore is in discontinuous tabular layers near the base of the formation or near sandstone bed pinchouts; vertical joints are mineralized in places where they intersect mineralized beds (Campbell, 1981). The sandstone of the Cutler Formation, which is often extensively bleached (possibly by mineralizing fluids), is as much as $50 \mathrm{ft}$ thick (Chenoweth, 1975). Uranium also occurs in the Permian Rico Formation, which is favorable for uranium occurrence beneath the study area (Campbell and others, 1982). Small uranium and vanadium deposits also occur in sandstone of the upper part of the Salt Wash Member of the Morrison Formation in the Moab mining area west of the Negro Bill Canyon Wilderness Study Area (Chenoweth, 1975). The Salt Wash Member of the Morrison Formation is eroded from the study area, but the Cutler, Rico, and Chinle Formations occur at depth beneath the study area.

Gold placer deposits have been reported from various places along the Colorado River adjacent to the study area boundary (Johnson, 1973). There are, however, no descriptions of the thicknesses of the gravels or gold distribution in the gravels. The gold apparently occurs as fine particles and is difficult to recover (Johnson, 1973). Source for the gold is probably in bedrock an unknown distance upstream, rather than from a local source (Johnson, 1973).

The Negro Bill Canyon Wilderness Study Area does not contain any known mineralized areas. Geochemical data indicate no concentrations of uranium or other metals in stream-sediment and concentrate samples collected from drainages in the study area.

The Chinle-Moenkopi contact is exposed in the lower part of Jackass Canyon (pl. 1) and outside the northern and eastern boundary of the study area. No mineralization was found either along the unconformity or in either of the formations. However, because

Figure 4 (facing page). Drill holes and inferred structure of the Precambrian surface in the vicinity of the Negro Bill Canyon Wilderness Study Area. Small circles with numbers indicate dritl holes mentioned in text. Elsewhere in the region, small circles indicate drill holes that have bottomed in Pennsylvanian or older rocks that provide control for estimates of the elevation of the Precambrian surface (Case and Joesting, 1972). $\mathrm{C}=$ Cambrian; $\mathrm{D}=$ Devonian; $\mathbf{M}=$ Mississippian. Numbers indicate elevation at total depth. Contour interval 1,000 ft. Heavy dashed lines indicate the approximate boundaries of the salt anticlines. Lines of section $D-D^{\prime}$ and $H-H^{\prime}$ show locations of gravity models from Case and Joesting (1973). Line $E-E^{\prime}$ is from Diggles and others (written commun.). 


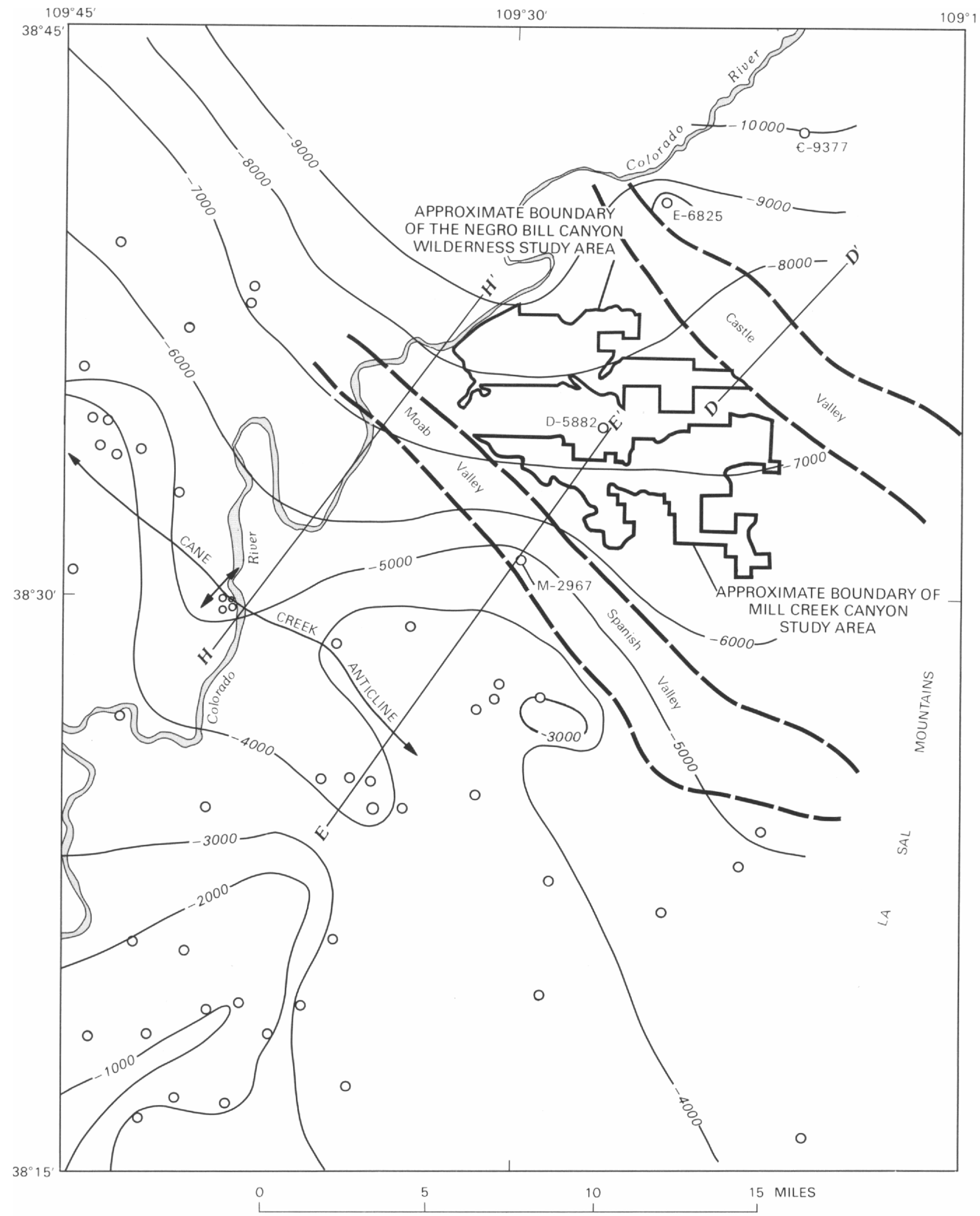




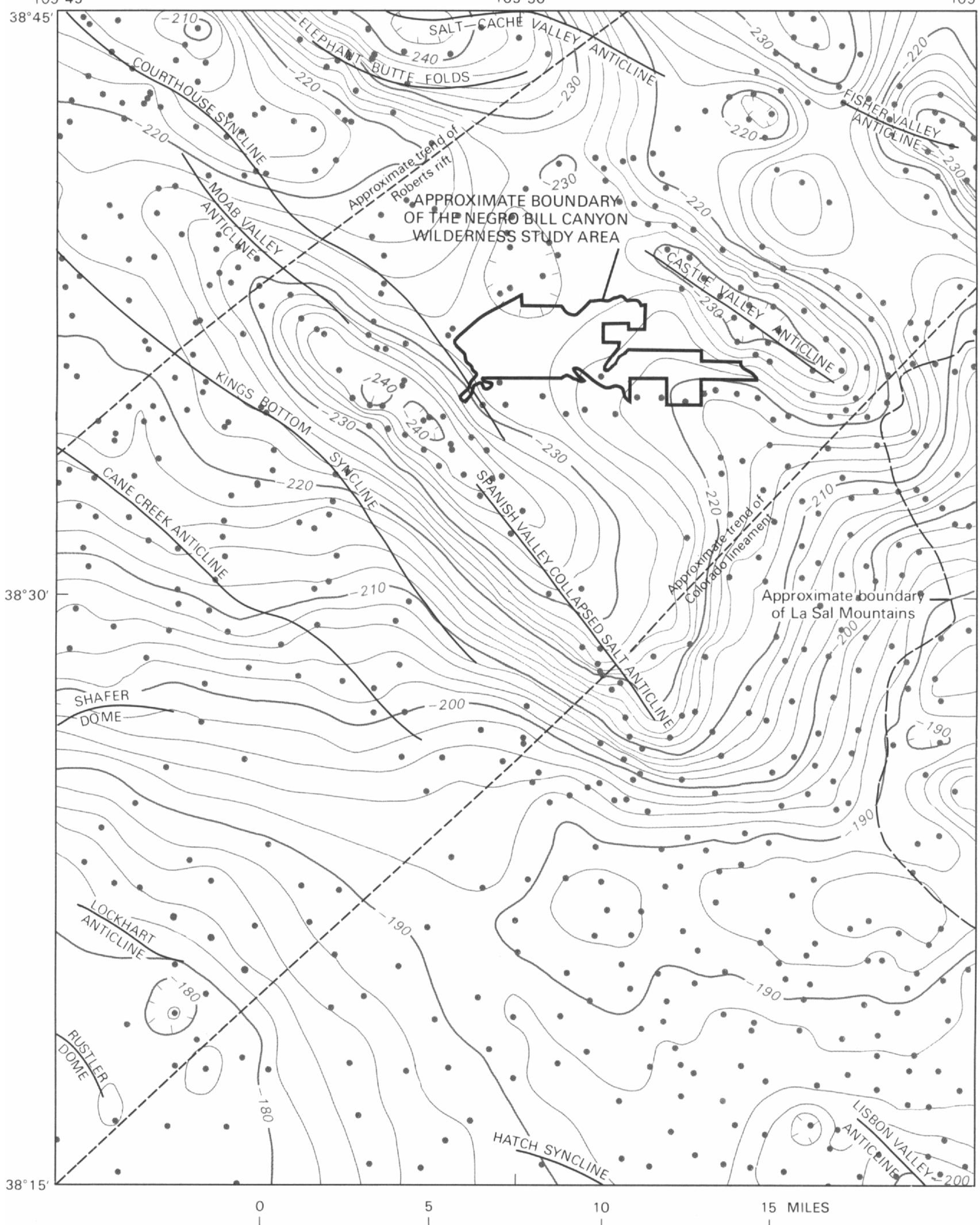

Figure 5. Bouguer anomaly map of the Negro Bill Canyon Wilderness Study Area and vicinity, Utah. Contour interval 2 milligals. Hachures show closed areas of lower gravity values. Dots are gravity stations. Some surficial structural features shown. Modified from Hildenbrand and Kucks (1983), and Patterson and others (1988). 


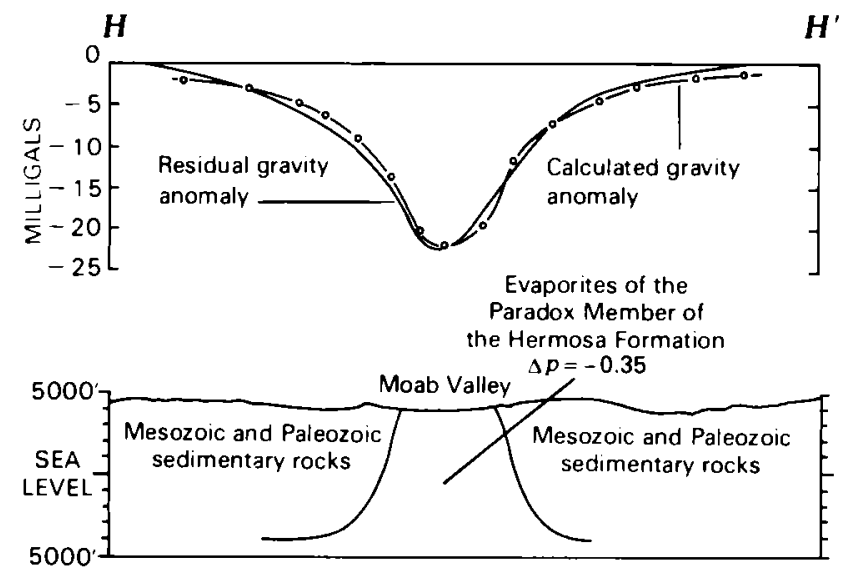

0
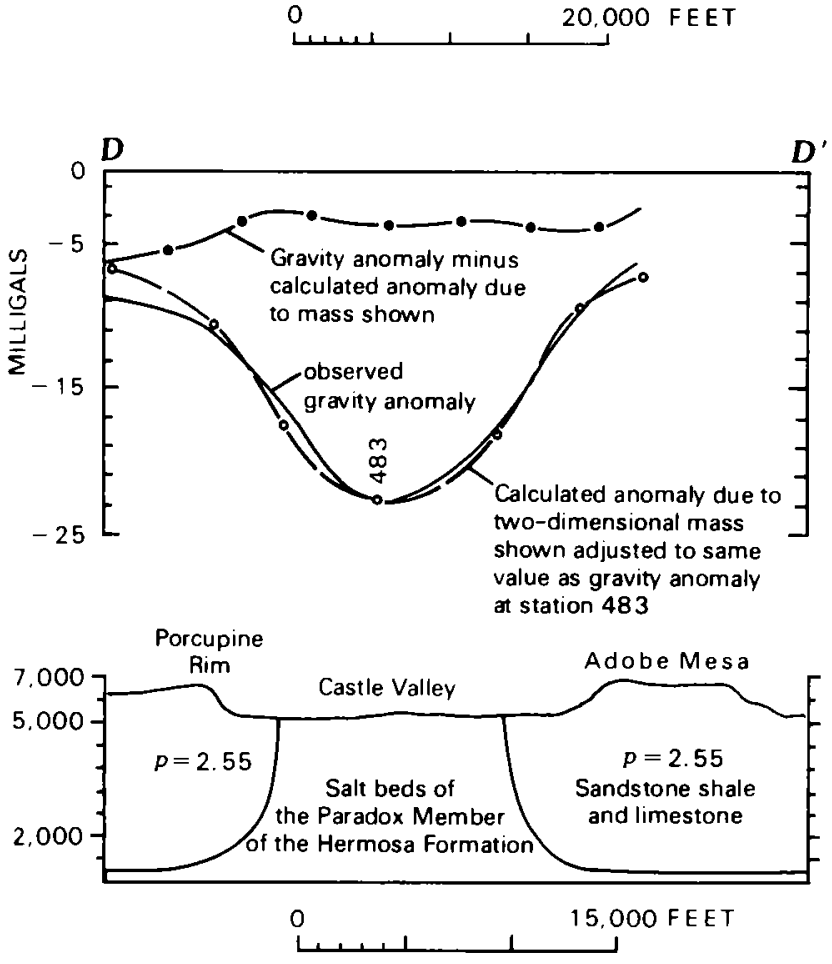

Figure 6. Interpretation of the residual gravity anomalies: (Upper), Over Moab Valley anticline along part of profile $H-H^{\prime} . \Delta_{p}$, density contrast. Location of profile is shown in figure 5. (Lower), Over Castle valley anticline ( $\left.D-D^{\prime}\right) . \rho$, density in grams per cubic centimeter. Location of profile is shown in figure 5 . (From Case and Joesting, 1972).

uranium mineralization occurs near Lisbon Valley adjacent to the study area, the mineral resource potential for thin, discontinuous beds containing uranium and vanadium in the Chinle and Moenkopi Formations at depths of less than 1,000 ft and in the Cutler Formation at greater depths beneath the Negro Bill Canyon Wilderness Study Area is rated as moderate with certainty level B. Although small gold placers may exist on the Colorado River adjacent to the study area boundary, their source is probably not local but rather from bedrock sources miles upstream. No other metals have been reported from the study area and geochemical data did not reveal any concentrations of metals. Thus, the Negro Bill Canyon Wilderness Study Area has low mineral resource potential for metals other than uranium and vanadium with certainty level $\mathrm{C}$.

\section{Potash and Halite}

Calcium sulfate and related salt minerals apparently form in two environmental settings: (1) in restricted large standing water bodies that evaporate to the point of gypsum deposition and (2), in restricted tidal flats or desert environments where brine near the surface (in the aerated zone) is concentrated by evaporation and precipitation (Blatt and others, 1972). The brine becomes increasingly concentrated when the evaporation rate exceeds input of more dilute solution (seawater or reconstructed brine). Such an environment need not be a hot climate, but one of limited rainfall; modern gypsum has been reported from arctic and subarctic conditions (Blatt and others, 1972).

Potash salt is mined from the Paradox Member on Cane Creek anticline west of Moab and the study area. Due to salt flowage, the Paradox in this area is about $5,000 \mathrm{ft}$ thick, as indicated by well data (Baars and Molenaar, 1971). The Paradox contains calcium sulfates including gypsum, anydrite, halite, and bedded bittern salts of potassium and magnesium (Blatt and others, 1972, table 15-2). A sylvite bed from about 4 to $40 \mathrm{ft}$ thick occurs in a saline facies of the Paradox at about 3,000 ft depth (Baars and Molenaar, 1971). The technique used to recover the potash is one of solution mining, wherein water is injected into the sylvite layers at depth where the geothermal gradient has heated the surrounding country rock to about $100{ }^{\circ} \mathrm{C}$, the heated fluid dissolves the salt deposits, potash-rich brine is brought to the surface, and evaporation ponds concentrate the salt, which is then bulldozed, processed, and shipped. The Cane Creek Mine located near Moab west of the study area produces about 1,000 to 1,200 tons per day, 261 days a year, and is expected to do so until about 1995 (Phillips, 1975).

Because the study area is adjacent to a producing potash deposit but geophysical evidence is equivocal as to the occurrence of the Paradox at depth, the mineral resource potential for potash salt and halite at considerable depth beneath the Negro Bill Canyon Wilderness Study Area is rated as high with certainty level C. 


\section{Gypsum}

Gypsum, a chemical precipitate, commonly originates in inland sabkha (salt flat) and desert-lake settings in basins with limited rainfall and where rapid evaporation takes place (Reineck and Singh, 1975). Gypsum typically occurs in evaporite deposits or in extensive beds interstratified with limestone, shale, and clay. The Chinle Formation, exposed on the edge of the Negro Bill Canyon Wilderness Study Area contains small localized gypsum beds. The mineral resource potential for small localized beds of gypsum in the Chinle Formation at a depth of less than 1,000 ft and for thick beds in the Paradox beds (see discussion above for potash and halite) at greater depth beneath the Negro Bill Canyon Wilderness Study Area is rated as high with certainty level C.

\section{Bentonite}

Bentonite is a term applied to various colloidal or plastic clays, or swelling clays. As such, the clays are able to take up water or organic liquids between their structural layers, as well as exchange cations readily. Dispersions of bentonite display the property of thixotropy. Bentonite is especially useful to the oil industry in drilling operations; it is also useful in the preparation of ceramics, paper, rubber, paints, and moulding sands (Deer and others, 1966).

Bentonite is formed by in situ alteration of volcanic ash; the deposits containing bentonite may be either marine or nonmarine. Beds of bentonite are typically less than $1 \mathrm{ft}$ thick, but there are rare occurrences of beds up to $50 \mathrm{ft}$ thick. Usually several tens of thin bentonitic beds might occur in a formation separated by clastic or tuffaceous units (Blatt and others, 1972). The chemical composition of bentonite is complex and variable, though calcic montmorillonite (with small amounts of magnesium) is the most common bentonite clay type in the western United States and Canada (Blatt and others, 1972; Dana, 1963).

Bentonite is a constituent of rocks in the lower part of the Chinle Formation. Bentonitic beds are typically less than a few inches to a few feet thick, and are dispersed throughout the units.

The resource potential for thin and dispersed bentonite beds in the lower part of the Chinle Formation exposed in the lower part of Jackass Canyon, and at depths of less than 1,000 ft beneath the Negro Bill Canyon Wilderness Study Area is rated as high with certainty level $\mathrm{C}$.

\section{Carbon Dioxide and Helium Gases}

Carbon dioxide and helium gases may accumulate in petroleum reservoirs; helium is a known component of, and is commonly extracted from, natural gas. Both are rated as strategic and critical gases.

Carbon dioxide is important in oil recovery enhancement techniques like those used in West Texas oil fields. Since carbon dioxide is miscible with oil, it acts as a solvent, displacing enough water to mobilize oil in water-invaded reservoirs from which oil would otherwise be unrecoverable. The largest carbon dioxide gas reservoirs are the McElmo Dome and Doe Canyon fields located near the Four Corners area of Colorado, with the host rock being the Leadville Limestone of Mississippian age. Presumably, carbon dioxide gas was created in this carbonate reservoir when the water-filled formation was subjected to high pressure and temperature alteration during deep-seated volcanism.

One of the wells in the Lisbon Valley Field was analyzed for comparative gases in the Mississippian reservoir; according to the analyses, only trace amounts of helium gas occurs in one of the wells, and the other wells contain moderate amounts of carbon dioxide gas (Parker, 1981). Given the proximity of the Lisbon Valley Field to the Negro Bill Canyon Wilderness Study Area, the energy resource potential for helium gas is low with certainty level $B$, and the energy resource potential for moderate amounts of carbon dioxide gas is moderate with certainty level $\mathrm{B}$.

\section{Geothermal Sources}

Geothermal sources are lacking within the Colorado Plateau except along the edges where volcanic rocks are found. No thermal springs were observed in the study area. Igneous rocks that crop out on the Colorado Plateau are generally between 17 and 65 million years old (Luedke and Smith, 1978); according to some investigators, these rocks are too old to be a viable source of heat necessary to produce geothermal activity. In addition, stream incision has caused lowering of the ground water table and has exposed Mesozoic rocks, the most viable geothermal reservoirs in the study area. Paleozoic rocks at depth have been shown to have some water reservoir potential (Thackston and others, 1981). There is little possibility of plutonic activity at depth beneath the study area, though igneous rocks occur adjacent to the study area (La Sal Mountains). While a geothermal occurrence cannot be ruled out, the Negro Bill Canyon Wilderness Study Area has low potential for geothermal sources with a certainty level of $B$.

\section{REFERENCES CITED}

Abdel-Gawad, A.M., and Kerr, P.F., 1963, Alteration of Chinle siltstone and uranium emplacement, Arizona and Utah: Geological Society of America Bulletin, v. 74, p. 23-46. 
Baars, D.L., 1975, The Permian System of Canyonlands Country, in Fassett, J.E., ed., Canyonlands Country: Four Corners Geological Society Guidebook, 8th Field Conference, Canyonlands, p. 123-127.

Baars, D.L., and Molenaar, C.M., 1971, Geology of Canyonlands and Cataract Canyon, in Fassett, J.E., ed., Canyonlands Country: Four Corners Geological Society Sixth Field Conference, Cataract Canyon River Expedition, $99 \mathrm{p}$.

Baars, D.L., and Seager, W.R., 1970, Stratigraphic control of petroleum in White Rim Sandstone (Permian) in and near Canyonlands National Park, Utah: American Association of Petroleum Geologists Bulletin, v. 54, p. 709-718.

Baker, A.A., 1933, Geology and oil possibilities of the Moab district, Grand and San Juan Counties, Utah: U.S. Geological Survey Bulletin 841, 95 p.

Bates, R.L., 1960, Geology of the industrial rocks and minerals: New York, Dover Publications, Inc., 459 p.

Blatt, Harvey, Middleton, Gerard, and Murray, Raymond, 1972, Origin of Sedimentary Rocks: Englewood Cliffs, New Jersey, Prentice-Hall, Inc., 634 p.

Bradley, G.A., 1975, Lisbon Field, Utah, in Fassett, J.E., ed., Canyonlands Country: Four Corners Geological Society Guidebook, 8th Field Conference, p. 277.

Campbell, J.A., 1981, Uranium mineralization and depositional facies in the Permian rocks of the northern Paradox Basin, Utah and Colorado: in Wiegand, D.L., ed., Geology of the Paradox Basin; Rocky Mountain Association of Geologists, 1981 field conference, p. 187-194.

Campbell, J.A., Franczyk, K.J., Lupe, R.D., and Peterson, Fred, 1982, National uranium resource evaluation, Moab quadrangle, Colorado and Utah: U.S. Department of Energy Report PGJ-F-056(82) (prepared by the U.S. Geological Survey), 68 p., 15 fiche. [Available from U.S. Geological Survey, Book and Open-File Reports Section, Box 25425, DFC, Denver, CO 80225.]

Case, J.E., and Joesting, H.R., 1972, Regional geophysical investigations in the central Colorado Plateau: U.S. Geological Survey Professional Paper 736, $31 \mathrm{p}$.

Case, J.E., Joesting, H.R., and Byerly, P.E., 1963, Regional geophysical investigations in the La Sal Mountains area, Utah and Colorado: U.S. Geological Survey Professional Paper 316-F, p. 97-116.

Chenoweth, W.L., 1975, Uranium deposits of the Canyonlands area, in Fassett, J.E., ed., Canyonlands Country: Four Corners Geological Society Guidebook, 8th Field Conference, p. 253-260.

Coope, B.M., and Harben, P.W., 1977, Silica sand, in Harben, P.W., ed., Raw Materials for the Glass Industry: London, Metal Bulletin, 131 p.

Cross, Whitman, 1907, Stratigraphic results of a reconnaissance in western Colorado and eastern Utah: Journal of Geology, v. 15 , p. 634-679.

Dana, E.S., 1963, A Textbook of Mineralogy, Revised and Enlarged, by W.E. Ford, 4th edition: New York, John Wiley and Sons, Inc., $851 \mathrm{p}$.
Dane, C.H., 1935 (1936), Geology of the Salt Valley anticline and adjacent areas, Grand County, Utah: U.S. Geological Survey Bulletin 863, 184 p.

Deer, W.A., Howie, R.A., and Zussman, J., 1966, An Introduction to the Rock-Forming Minerals: New York, John Wiley and Sons, Inc., $528 \mathrm{p}$.

Doelling, H.H., 1975, Geology and mineral resources of Garfield County, Utah: Utah Geological and Mineral Survey Bulletin 107, 175 p.

Dubiel, R.F., Blodgett, R.H.,, and Bown, T.M., 1987a, Lungfish burrows in the Upper Triassic Chinle and Dolores Formations, Colorado Plateau: Journal of Sedimentary Petrology, v. 57, no. 3, p. 512-521.

$1987 \mathrm{~b}$, Lungfish burrows in the Upper Triassic Chinle and Dolores Formations, Colorado Plateau-Reply: Journal of Sedimentary Petrology, v. 58, no. 2, p. 367-369.

Dutton, C.E., 1880, Report on the geology of the High Plateaus of Utah: U.S. Geographical and Geological Survey, Rocky Mountain Region, 1880.

1882a, The physical geology of the Grand Canyon district: U.S. Geological Survey Second Annual Report, p. $47-166$.

$1882 \mathrm{~b}$, Tertiary history of the Grand Canyon district: U.S. Geological Survey Monograph 2, 264 p.

Duval, J.S., 1983, Composite color images of aerial gamma-ray spectrometric data: Geophysics, v. 48, p. 722-735.

Freeman, W.E., and Visher, G.S., 1975, Stratigraphic analysis of the Navajo Sandstone: Journal of Sedimentary Petrology, v. 45, no. 3, p. 651-668.

Goudarzi, G.H., compiler, 1984, Guide to preparation of mineral survey reports on public lands: U.S. Geological Survey Open-File Report 84-787, 42 p.

Hasiotis, S.T., and Mitchell, C.E., 1989, Lungfish burrows in the Upper Triassic Chinle and Dolores Formations, Colorado Plateau-Discussion: New evidence suggests origin by a burrowing decapod Crustacean: Journal of Sedimentary Petrology, v. 59, no. 5, p. 871-875.

Hemphill, W.R., 1955, Photogeologic map of the Moab-16 quadrangle, Grand County, Utah: U.S. Geological Survey Miscellaneous Geologic Investigations Map I-83, scale $1: 24,000$.

Hildenbrand, T.G., and Kucks, R.P., 1983, Regional magnetic and gravity features of the Gibson dome area and surrounding region, Paradox Basin, Utah-A preliminary report: U.S. Geological Survey Open-File Report 83-359, 34 p.

Joesting, H.R., Case, J.E., and Plouff, Donald, 1966, Regional geophysical investigations in the Moab-Needles area, Utah: U.S. Geological Survey Professional Paper 516-C, p. C1-C21.

Johnson, M.G., 1973, Placer gold deposits of Utah: U.S. Geological Survey Bulletin 1357, 26 p.

Lane, M.E., 1989, Mineral investigation of the Negro Bill Canyon (UT-060-138) and Mill Creek Canyon (UT-060-139A) Wilderness Study Areas, Grand County, Utah: U.S. Bureau of Mines Open-File Report MLA 28-89, 11 p. 
Lee, W.T., 1918, Early Mesozoic physiography of the southern Rocky Mountains: Smithsonian Miscellaneous Collections, v. 69 , no. 4,41 p.

Lewis, G.E., Irwin, J.H., and Wilson, R.F., 1961, Age of the Glen Canyon Group on the Colorado Plateau: Geological Society of America Bulletin, v. 72, no. 9, p. $1437-1440$.

Luedke, R.G., and Smith, R.C., 1978, Map showing distribution, composition, and age of late Cenozoic volcanic centers in Colorado, Utah, and southwestern Wyoming: U.S. Geological Survey Miscellaneous Investigations Series Map I-1091-B, scale 1:1,000,000.

Mahoney, S.R., and Kunkel, R.P., 1963, Geology and oil and gas possibilities of east-central Utah, in Crawford, A.L., ed., Oil and gas possibilities of Utah, re-evaluated: Utah Geological and Mineral Survey, Bulletin 54, p. 353-380.

McAllister, J.A., 1987, Lungfish burrows in the Upper Triassic Chinle and Dolores Formations, Colorado PlateauComments on the recognition criteria of fossil lungfish burrows: Journal of Sedimentary Petrology, v. 58, no. 2, p. 365-366.

McKnight, E.T., 1940, Geology of area between Green and Colorado Rivers, Grand and San Juan Counties, Utah: U.S. Geological Survey Bulletin 908, 147 p.

Molenaar, C.M., 1981, Mesozoic stratigraphy of the Paradox basin-an overview, in Geology of the Paradox Basin: 1981 Field Conference, Rocky Mountain Association of Geologists Guidebook, p. 119-127.

1987, Mesozoic rocks of Canyonlands country, in Fassett, J.E., ed., Cataract Canyon: Four Corners Geological Society Guidebook, Tenth Field Conference, p. 19-24.

Molenaar, C.M., and Sandberg, C.A., 1983, Petroleum potential of wilderness lands in Utah, in Miller, B.M., ed., Petroleum potential of wilderness lands in the western United States: U.S. Geological Survey Circular 902-K, p. K1-K14.

Newberry, J.S., 1876, Geological report, in Macomb, J.N., Report of the exploring expedition from Santa Fe, New Mexico, to the junction of the Grand and Green Rivers of the Great Colorado of the West in 1859: U.S. Army, Engineer Department, p. 9-118.

O'Sullivan, R.B., and MacLachlan, M.E., 1975, Triassic rocks of the Moab-White Canyon area, southeastern Utah: Four Corners Geological Society Guidebook, Eighth Field Conference, Canyonlands, p. 129-141.

Papulak, M.S., 1963, Oil and gas occurrences in the proposed Canyonlands National Park area of southern Utah, in Crawford, A.L., ed., Oil and gas possibilities of Utah, re-evaluated: Utah Geological and Mineral Survey, Bulletin 54, p. 447-467.

Parker, J.M., 1981, Lisbon Field area, San Juan County, Utah: Rocky Mountain Association of Geologists-1981 Field Conference, p. 89-100.

Patterson, C.G., Toth, M.I., Case, J.E., Green, G.N., Barton, H.N., and Thompson, J.R., 1988, Mineral resources of the Behind the Rocks Wilderness Study Area, Grand and
San Juan Counties, Utah: U.S. Geological Survey Bulletin 1754-B, p. B1-B18.

Peale, A.C., 1877, Geological report on the Grand River district: U.S. Geological and Geographical Survey Territory Ninth Annual Report, p. 31-303.

Peterson, Fred, and Pipiringos, G.N., 1979, Stratigraphic relations of the Navajo Sandstone to Middle Jurassic formations, southern Utah and northern Arizona: U.S. Geological Survey Professional Paper 1035-B, 43 p.

Phillips, Margie, 1975, Cane Creek Mine solution mining project, Moab potash operations, Texasgulf, Inc.: Four Corners Geological Society Guidebook, 8th Field Conference, Canyonlands, p. 261.

Pipiringos, G.N., and O'Sullivan, R.B., 1975, Chert pebble unconformity at the top of the Navajo Sandstone in southeastern Utah, in Fassett, J.E., ed., Canyonlands country: Four Corners Geological Society Guidebook, 8th Field Conference, p. 149-156.

Poole, F.G., 1961, Stream directions in Triassic rocks of the Colorado Plateau: U.S. Geological Survey Professional Paper 424-C, p. C139-C141.

Powell, J.W., 1875, Exploration of the Colorado River of the West and its tributaries, 1869-1872: Smithsonian Institution, $291 \mathrm{p}$.

Quigley, W.D., 1963, Basement rocks and relationship to overlying sediments of the Paradox Basin, in Crawford, A.L., ed., Oil and gas resources of Utah, re-evaluated: Utah Geological and Mineral Survey Bulletin 54, p. 387-403.

Reineck, H.-E., and Singh, I.B., 1975, Depositional Sedimentary Environments: New York, Springer-Verlag, $439 \mathrm{p}$.

Richmond, G.M., 1962, Quaternary stratigraphy of the La Sal Mountains, Utah: U.S. Geological Survey Professional Paper 324, $135 \mathrm{p}$.

Smith, K.T., 1981, Preface, Geology of the Paradox Basin: Rocky Mountain Association of Geologists, 285 p.

Smith, K.T., and Prather, O.E., 1981, Lisbon Field-lessons in exploration: Rocky Mountain Association of Geologists, 1981 Field Conference, p. 55-59.

Spencer, C.W., 1975, Petroleum geology of east-central Utah and suggested approaches to exploration, in Fassett, J.E., ed., Canyonlands Country: Four Corners Geological Society Guidebook, 8th Fielc Conference, p. 263-275.

Stanley, K.O., Jordan, W.M., and Dott, R.H., Jr., 1971, Early Jurassic paleogeography and sediment dispersal for western Untied States: American Association of Petroleum Geologists Bulletin, v. 55, no. 1, p. 10-19.

Stewart, J.H., Poole, F.G., and Wilson, R.F., 1972, Stratigraphy and origin of the Chinle Formation and related Upper Triassic strata in the Colorado Plateau region: U.S. Geological Survey Professional Paper 690, $336 \mathrm{p}$.

Thackston, J.W., McCulley, B.L., and Preslo, L.M., 1981, Groundwater circulation in the Western Paradox basin, Utah, in Wiegand, D.L., ed., Geology of the Paradox Basin: Rocky Mountain Association of Geologists, 1981 Field Conference, p. 201-225. 
Thornbury, W.D., 1965, Regional geomorphology of the United States: New York, John Wiley, 609 p.

Turner-Peterson, C.E., and Hodges, C.A., 1986, Descriptive model of sandstone $U$, in Cox, D.P., and Singer, D.A. eds., Mineral deposit models: U.S. Geological Survey Bulletin 1693, p. 209-210.

U.S. Bureau of Mines, 1980, Helium-Its relationship to geologic systems and its occurrence with the natural gases, nitrogen, carbon dioxide, and argon: U.S.Bureau of Mines Report of Investigations RI-8444, 176 p.

1987, (with resource information by the U.S. Geological Survey), Mineral commodity summaries, 1987, $189 \mathrm{p}$.

U.S. Bureau of Mines and U.S. Geological Survey, 1980, Principles of a resource/reserve classification for minerals: U.S. Geological Survey Circular 831, 5 p. 

APPENDIX 


\title{
DEFINITION OF LEVELS OF MINERAL RESOURCE POTENTIAL AND CERTAINTY OF ASSESSMENT
}

\author{
Definitions of Mineral Resource Potential
}

LOW mineral resource potential is assigned to areas where geologic, geochemical, and geophysical characteristics define a geologic environment in which the existence of resources is unlikely. This broad category embraces areas with dispersed but insignificantly mineralized rock as well as areas with few or no indications of having been mineralized.

MODERATE mineral resource-potential is assigned to areas where geologic, geochemical, and geophysical characteristics indicate a geologic environment favorable for resource occurrence, where interpretations of data indicate a reasonable likelihood of resource accumulation, and (or) where an application of mineral-deposit models indicates favorable ground for the specified type(s) of deposits.

HIGH mineral resource potential is assigned to areas where geologic, geochemical, and geophysical characteristics indicate a geologic environment favorable for resource occurrence, where interpretations of data indicate a high degree of likelihood for resource accumulation, where data support mineral-deposit models indicating presence of resources, and where evidence indicates that mineral concentration has taken place. Assignment of high resource potential to an area requires some positive knowledge that mineral-forming processes have been active in at least part of the area.

UNKNOWN mineral resource potential is assigned to areas where information is inadequate to assign low, moderate, or high levels of resource potential.

NO mineral resource potential is a category reserved for a specific type of resource in a well-defined area.

\section{Levels of Certainty}

\begin{tabular}{|c|c|c|c|}
\hline \multirow{4}{*}{$\begin{array}{l}\text { UNKNOWN } \\
\text { POTENTIAL }\end{array}$} & $\begin{array}{l}\text { H/B } \\
\text { HIGH POTENTIAL }\end{array}$ & $\begin{array}{l}\text { H/C } \\
\text { HIGH POTENTIAL }\end{array}$ & $\begin{array}{l}\text { H/D } \\
\text { HIGH POTENTIAL }\end{array}$ \\
\hline & $\begin{array}{l}\text { M/B } \\
\text { MODERATE POTENTIAL }\end{array}$ & $\begin{array}{l}\text { M/C } \\
\text { MODERATE POTENTIAL }\end{array}$ & $\begin{array}{l}\text { M/D } \\
\text { MODERATE POTENTIAL }\end{array}$ \\
\hline & 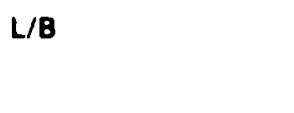 & $\mathrm{L} / \mathrm{C}$ & $\begin{array}{l}\text { L/D } \\
\text { LOW POTENTIAL }\end{array}$ \\
\hline & $\begin{array}{l}\text { LOW } \\
\text { POTENTIAL }\end{array}$ & $\begin{array}{l}\text { LOW } \\
\text { POTENTIAL }\end{array}$ & $\begin{array}{l}\text { N/D } \\
\text { NO POTENTIAL }\end{array}$ \\
\hline $\mathbf{A}$ & $\mathbf{B}$ & C & D \\
\hline
\end{tabular}

A. Available information is not adequate for determination of the level of mineral resource potential.

B. Available information suggests the level of mineral resource potential.

C. Available information gives a good indication of the level of mineral resource potential.

D. Available information clearly defines the level of mineral resource potential.

\section{Abstracted with minor modifications from:}

Taylor, R. B., and Steven, T. A., 1983, Definition of mineral resource potential: Economic Geology, v. 78, no. 6, p. $1268-1270$.

Taylor, R. B., Stoneman, R. J., and Marsh, S. P., 1984, An assessment of the mineral resource potential of the San Isabel National Forest, south-central Colorado: U.S. Geological Survey Bulletin 1638, p. $40-42$.

Goudari, G. H., compiler, 1984, Guide to preparation of mineral survey reports on public lands: U.S. Geological Survey Open-File Report 84-0787, p. 7, 8. 


\section{RESOURCE/RESERVE CLASSIFICATION}

\begin{tabular}{|c|c|c|c|c|c|}
\hline & \multicolumn{3}{|c|}{ IDENTIFED RESOURCES } & \multicolumn{2}{|c|}{ UNDISCOVERED RESOURCES } \\
\hline & \multicolumn{2}{|c|}{ Demonstrated } & \multirow{2}{*}{ Inferred } & \multicolumn{2}{|c|}{ Probability Range } \\
\hline & Measured & Indicated & & Hypothetical & Speculative \\
\hline ECONOMIC & Res & & Inferred Reserves & & \\
\hline $\begin{array}{l}\text { MARGINALLY } \\
\text { ECONOMIC }\end{array}$ & Margina & leserves & $\begin{array}{c}\text { Inferred } \\
\text { Marginal Reserves }\end{array}$ & & \\
\hline $\begin{array}{c}\text { SUB- } \\
\text { ECONOMIC }\end{array}$ & $\begin{array}{l}\text { Demol } \\
\text { Subeconon }\end{array}$ & $\begin{array}{l}\text { rated } \\
\text { Resources }\end{array}$ & $\begin{array}{c}\text { Inferred } \\
\text { Subeconomic } \\
\text { Resources }\end{array}$ & & \\
\hline
\end{tabular}

Major elements of mineral resource classification, excluding reserve bese and Inferred reserve base. Modified from McKolvey, 1972, Mineral resource estimates and public policy: American Scientist, v.60, p.32-40, and U.S. Bureau of Mines and U.S. Geoiogical Survey, 1980, Principles of a reciource/reserve claselfication for minerale: U.5. Geological Survey Circular 831, p.6. 
GEOLOGIC TIME CHART

Terms and boundary ages used in this report

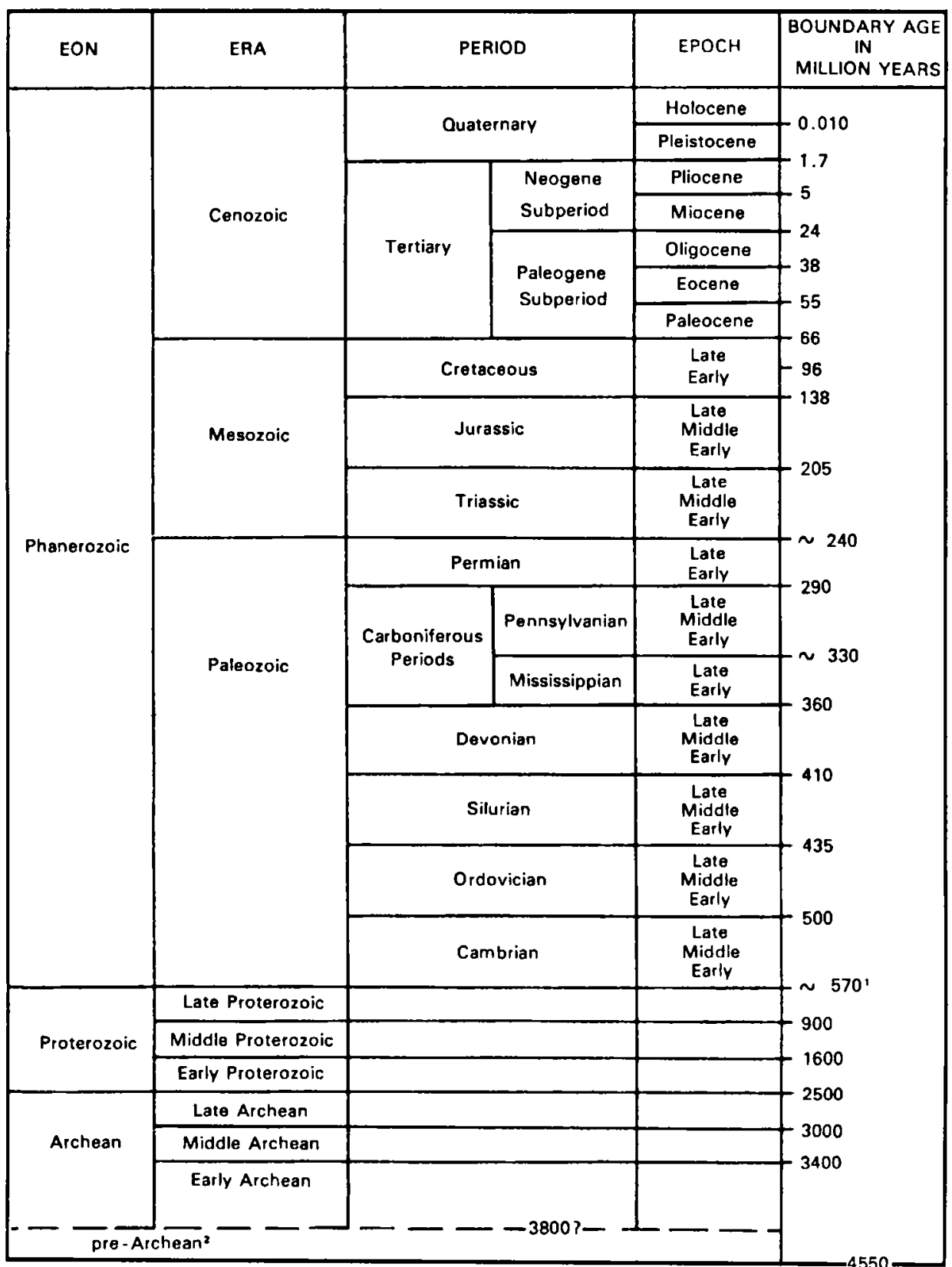

'Rocks older than $570 \mathrm{~m}$.y. also called Precambrian, a time term without specific rank.

${ }^{2}$ Informal time term without specific rank. 



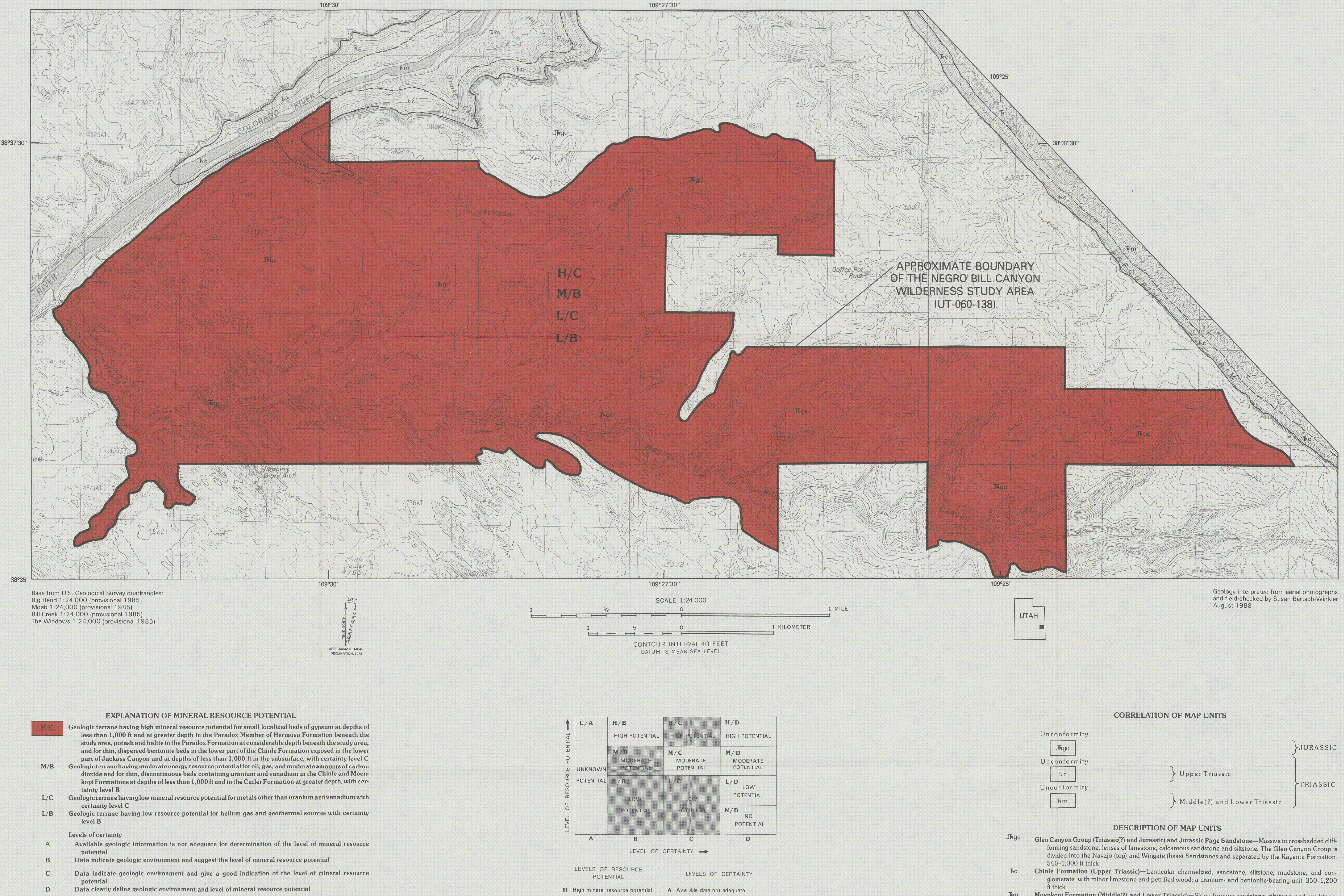

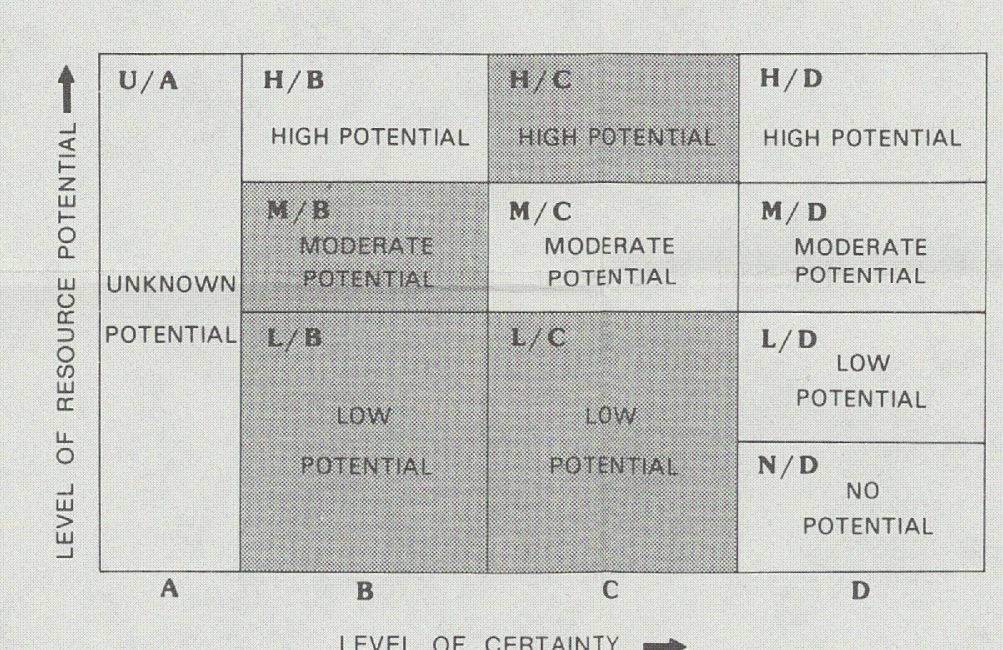

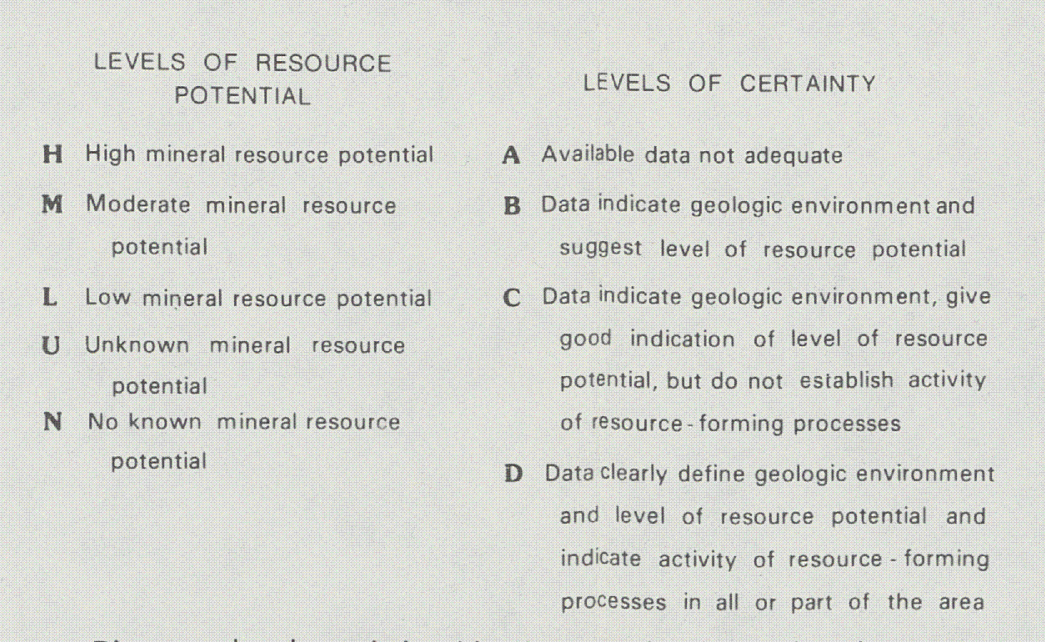

Diagram showing relationships between levels of minieral resource
potential and levels of cerrainty. Shading shows levels that apply to
this sal
CORRELATION OF MAP UNITS

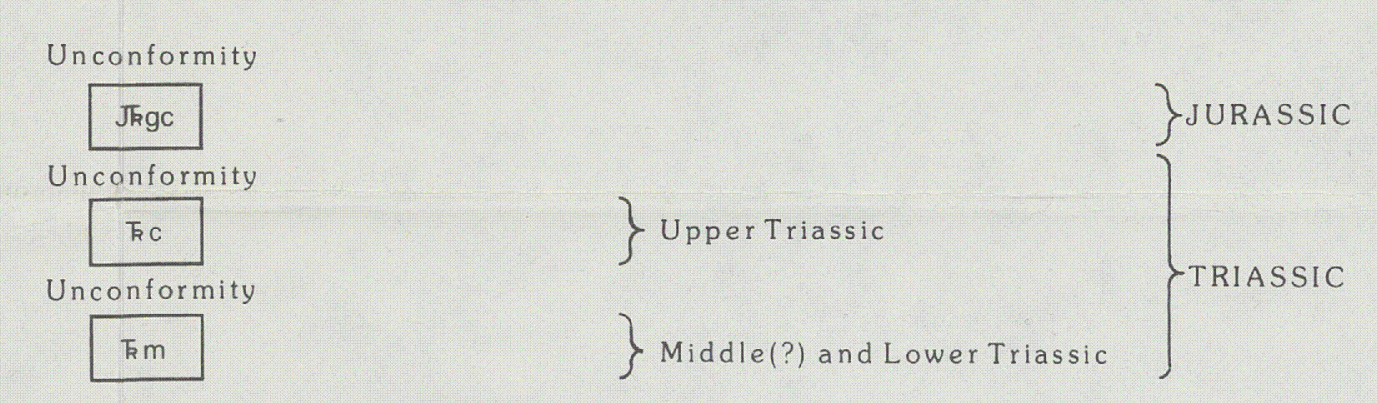

DESCRIPTION OF MAP UNITS

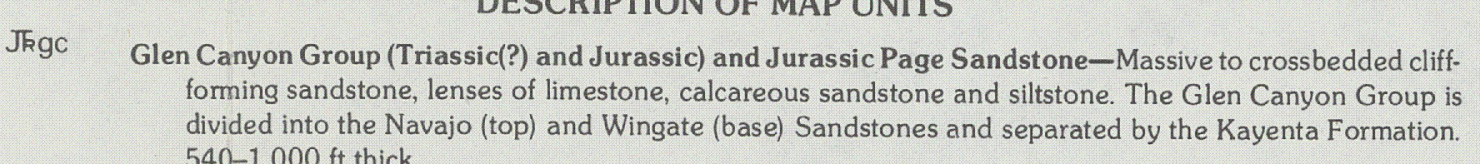

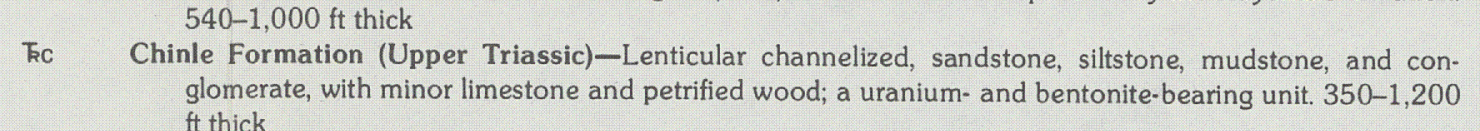

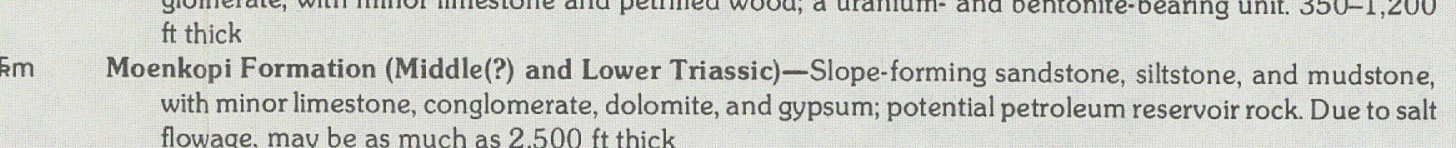
Contact, may be approximately located or concealed 
